\title{
Pietro Cataneo and the Fortified City The use of the grid plan
}

A Thesis Presented to the Department of Architectural History, School of Architecture, University of Virginia, In Partial Fulfillment of the Requirements for the Degree of Master of Architectural History

By

Kenta Tokushige

Bachelor of Architecture, Waseda University, 2008

Master of Architecture, Waseda University, 2012

Thesis Committee

Cammy Brothers, Chair

Lisa Reilly

Shiqiao Li.

April 2016 


\section{Table of Contents}

List of illustrations

$1 \quad$ Introduction

4 Chapter 1 The life of Pietro Cataneo

11 Chapter 2 The Taccuino and Pietro Cataneo's training as an architect

22 Chapter 3 Histriography of Fortified Cities

31 Chapter 4 The Change in the Interpretation of Vitruvius' Fortified City

$44 \quad$ Bibliography

$47 \quad$ Illustrations 


\section{List of Illustrations}

Figure

1 Pietro di Jacomo Catani descrisse et disegno in Siena addi xxiii di marzo 1533

2 Perspective drawing of a hexagonal fortification by Cataneo in his Taccuino

3 Perspective drawing of a hexagonal fortification by Francesco di Giorgio Martini in Codice Magliabechiano

4 Perspective drawing of a coastal city with a port by Cataneo in his Taccuino

5 Perspective drawing of a coastal city with a port by Francesco di Giorgio Martini in Codice Magliabechiano

6 Drawings of dams and weirs by Cataneo in his Taccuino

7 Drawings of dams and weirs by Cataneo in his Taccuino

8 Drawings of church plans by Cataneo in his Taccuino

9 Drawings of church plans by Francesco di Giorgio Martini in Codice Magliabechiano

10 Drawings of the cherub by Cataneo in his Taccuino

11 Drawings of the cherub by Giuliano da Sangallo in Taccuino Senese

12 The city of Sforzinda by Filarete

13 Wind diagram by Palladio

14 Plan of fortified city by Palladio based on Vtiruvius' De architettura

15 Detail plan of the bastion for the fortified city by Palladio

16 Example of a fortified city by Cataneo in I Quattro Primi Libri di Architettura

17 Wind diagram by Fra Giocondo

18 Street plan by Fra Gicondo

19 Wind diagram by Cesare Cesariano

20 City plan by Cesare Cesariano

21 Illustrations by Claude Perrault for his translation of Vtiruvius' De architettura 


\section{Introduction}

During the Quattrocento and Cinquecento, many architectural treatises were published in Italy and southern Europe. Pietro Cataneo, a Sienese architect, published his own treatise $I$ Quattro Primi Libri di Architettura in 1554. The content of the treatise included fortification, material, temple and palazzo. ${ }^{1}$ The majority of the treatise was related to the design of fortified cities, an indication of the demand for a new model of fortification due to the advancement of weaponry. The focus on a fortified city in an architectural treatise was unique in this era; however, many scholars considered the content unoriginal. As a result, Cataneo is not considered an important figure in Renaissance architecture.

Cataneo's treatise was the first published with illustrated series of different city plans. ${ }^{2}$ In all of the plans of the fortified city, Cataneo illustrated the street patterns, primarily using the grids. The street patterns in other contemporary architectural treatises were illustrated using the radial patterns. The popular use of radial patterns was a result of the Italian Renaissance architects' understanding of Vitruvius. The cities in early translations of Vitruvius' $D e$ architettura were drawn using radial patterns. Thus, the use of grid patterns by Cataneo deviated from what was considered the common understanding of De architettura in the first half of Cinquecento.

This thesis will explore not only how Pietro Cataneo became intensely interested and involved in designing fortified cities prior to the publication of his treatise but also the possibility

\footnotetext{
${ }^{1}$ It was followed by a publication of a revised edition published in 1567 with additional four books on the order, water and baths, geometry and perspective.

${ }^{2}$ Francesco di Giorgio Martini's Trattato di architettura has several pages with multiple plans of fortified cities. Although his treatise was widely distributed in manuscript format, it was never published.
} 
that his treatise, often considered insignificant, might have influenced how a fortified city was drawn in the translation of De architettura by Daniele Barbaro and Andrea Palladio in 1556, the most influential edition of De architettura in the latter half of the Cinquecento and on into the future. The primary source materials used in this thesis are Cataneo's treatise I Quattro Primi Libri di Architettura, Cataneo's notebook preserved at the Gabinetto Disegni e Stampe degli Uffizi, and the various editions of De architettura published during the Quattrocento and the Cinquecento. The treatise and the notebook are the only surviving works of Cataneo despite his known works of fortification in Maremma, Orbetello and Porto Ercole.

Chapter One will look at the life of Cataneo prior to the publication of his treatise to suggest the reason why he chose to apply grid patterns for the designs of the fortified cities in his treatise. The biography of Cataneo was written by Ettore Romagnoli based on the archival records from Siena. How Cataneo was educated in architecture and his ability to acquire knowledge of fortifications can only be understood through these archival records.

Chapter Two will analyze the drawings in Cataneo's notebook preserved at the Gabinetto Disegni e Stampe degli Uffizi, often referred to as the Taccuino, to understand how Cataneo actually formed his idea during his training as an architect. The content of the Taccuino is a reproduction of works by Francesco di Giorgio Martini and Giuliano da Sangallo. It is believed to have been produced during Cataneo's early training as an architect. The way in which Cataneo reproduces the works of his predecessors demonstrates the formation of his idea and how he prioritized his amassed knowledge.

Chapter Three will examine the ideal and fortified cities illustrated in architectural treatises before and after Cataneo to understand the tradition of fortified city design. I will examine the works of Leon Battista Alberti, Filarete, Francesco di Giorgio Martini and later 
military architects. The cities described by Alberti have generally been understood as applying radial pattern, and Filarete and Francesco di Giorgio have illustrated their cities using radial pattern. ${ }^{3}$ Military architects also utilize radial pattern based on military efficiency. Therefore, Cataneo can be regarded being unique in his time.

Chapter Four will address the influence of Cataneo's treatise on Daniele Barbaro and Andrea Palladio's translation of De architettura. Because there were no illustrations accompanying the treatise by Vitruvius when found, numerous illustrations were drawn by architects during the Renaissance. However, prior to Daniele Barbaro's translation accompanying Andrea Palladio's drawing in 1556, cities were drawn with radial street pattern. By comparing the various interpretations of Vitruvius's De architettura concerning fortified cities through the Quattrocento and Cinquecento, I will examine the possible influence of Cataneo and his treatise on the new interpretation of Vitruvius by Venetian scholars in the late Cinquecento.

The comparison of Cataneo's illustration of fortified cities along with the traditional understanding of Vitruvius's De architettura will shed light on an architect who has long been considered insignificant. The other surviving materials will supplement how Cataneo was able to formulate his ideas prior to the publication of his treatise, which influenced Daniele Barbaro and Andrea Palladio.

\footnotetext{
${ }^{3}$ Francesco di Giorgio draws cities both using radial pattern and grid pattern.
} 


\section{Chapter One}

\section{The Life of Pietro Cataneo}

Understanding the life of Pietro Cataneo, prior to the publication of his treatise $I$ Quattro Primi Libri di Architettura in 1554, is important in considering why he interpreted Vitruvius' De architettura differently from other contemporary architects. Studying the biography written by Ettore Romagnoli, the only source indicating how Cataneo was trained as an architect and the works he administered for the Republic of Siena, will give us possible hints about why he was extremely involved in the design of a fortified city. ${ }^{4}$

The primary source for understanding Cataneo's life is the archival record preserved at Archivio di Stato di Siena. The content of the record is mainly contracts and letters between Cataneo and the Republic of Siena. Based on these archival records, Ettore Romagnoli (17721838) wrote seventy pages on the life of Cataneo in his Biografia Cronologica De' Bellartisti Senesi 1200 - 1800. Romagnoli was a Sienese member of the Società Colombaria Fiorentina, a society established in 1732 for the study of history, literature, science and fine arts. He donated the biography to the Biblioteca di Siena in 1835. The biography is composed of twelve volumes and 11,000 pages. Many contemporary historians such as, Carl Friedrich von Rumohr, Giovanni Gaye and Gaetano Milanesi have cited this biography.

Cataneo's involvement in fortification design is apparent even from the earliest record of his architectural activity. The first time he was mentioned working on an architectural project was in 1544 , when three payments were made to Cataneo for the construction of fortification in

\footnotetext{
${ }^{4}$ Cataneo is not mentioned by Vasari in his Le Vite de' più eccellenti pittori, scultori, e archi tettori da Cimabue insino a' tempi nostri, suggesting that he was not considered an important figure even in his own time.
} 
Orbetello, a coastal city in the Republic of Siena. ${ }^{5}$

Apotissarum ai 27 Maggio 1544: mi dice, che dal mag Gio Landucci furono pagate $£ 214$ a Pier Cataneo \& la muraglia d'Orbetello come a Carte 86: ... adi 4 Giugno furono pagate $£ 480$ al commissario Pier Cataneo a Orbetelo,..., furono pagate $£ 333$ a orbetello al Cataneo. $^{6}$

The year before, in 1543, the Turkish fleet, led by Hayreddin Barbarossa, sacked the Tuscan coastal cities of Monteano, Talamone and Portercole. Refortification was an urgent matter for the region. Cataneo had been sent to Orbetello, Grosetto, Talamone, Portecole and Montauto, coastal cities of the Republic, to work on strengthening the fortification of these municipalities. Payments to Cataneo for his work on these fortifications continued until 1550.

In 1552, Siena was under the control of the Spanish garrison placed there by the Holy Roman Emperor Charles V. On July 26, French and Italian forces led by Enea Piccolomini delle Papese forced the Spaniards out of the city. The city was back in the hands of the Republic, but there was constant threat of the Spanish returning. Cataneo was employed to improve the fortifications of cities near Siena: Caparbio, Montalcino, Asinalunga and Campagnatico. However, when war erupted between the Republic and the Spaniards in the succeeding years, Cataneo does not appear on any of the Republic's records.

The publication of Cataneo's treatise was in 1554 in Venice. After he finished refortifying the surrounding cities in 1552, Cataneo may have been in Venice during the most critical time for Siena. After he published his treatise, there are no records suggesting that he was commissioned for a new project. In 1555, Siena became part of the Grand Duchy of Tuscany and

\footnotetext{
${ }^{5}$ Ettore Romagnoli, Biografia Cronologica de' Bellartisti Senesi 1200-1800 Volume VII (Firenze: Edizioni S.P.E.S, 1976), 180.

${ }^{6}$ Romagnoli, Biografia Cronologica de’ Bellartisti Senesi 1200-1800 Volume VII, 181.
} 
was therefore under the control of the Medici family. It is therefore possible that the Medicis had a more favorable architect for the public works commission and Cataneo did not receive as much work as he did before. Additionally, Siena was no longer at war and did not require further improvements to its fortifications, Cataneo's specialty.

Although, a number of records indicate Cataneo's involvement with the planning of the fortification for the Republic. The reason for Cataneo's appointment as an architect for such an important project is unclear.

Cataneo's occupation prior to 1544 was as a scrittore e computista for the Republic. ${ }^{7,8}$ The archival record from July 1539 mentions him receiving a stipend for his work. ${ }^{9}$ Like his father before him, Cataneo's first known occupation was not as an architect but as the record keeper for the Republic.

Why would a record keeper be appointed as an architect for one of the most critical projects of the Republic? Between his the years as a record keeper and being appointed the architect for refortifying the cities, there are only records concerning Cataneo living with his brother Bernardino and his marriage. ${ }^{10}$ One possible explanation is that while Cataneo was working for the Republic as a record keeper, he was also working as a private architect. Milanese mentions Baldassare Peruzzi entrusting the unfinished projects to Cataneo on his return to Rome. ${ }^{11}$ If true, it suggests that Cataneo had been working as an architect for the Republic since

\footnotetext{
${ }^{7}$ Scritture; 1. legal papers. 2. the business records of a firm, or the general records except the account books (Florence Edler, Glossary of Mediaeval Terms of Business: Italian Series 12001600 (Cambridge: The Mediaeval Academy of America, 1934) 266)

${ }^{8}$ Computista: 1 . computer, reckoner (in the $15^{\text {th }}$ century) 2. a (salaried) bookkeeper (in a firm, in the $16^{\text {th }}$ century) (Edler, Glossary of Mediaeval Terms of Business, 82)

${ }^{9}$ Romagnoli, Biografia Cronologica de' Bellartisti Senesi 1200-1800 Volume VII, 180.

${ }^{10}$ Romagnoli, Biografia Cronologica de’ Bellartisti Senesi 1200-1800 Volume VII, 180.

11 "Milanesi adds that Peruzzi held Cataneo in such high esteem that on returning to Rome he
} 
1535, when Peruzzi returned to Rome. ${ }^{12}$ However, I was unable to find any archival record of Cataneo's architectural work prior to 1544 .

Romagnoli and many others have mentioned that Cataneo was trained in architecture under Baldassare Peruzzi (1481-1536), however, no evidence exists to support that assumption. Peruzzi, also a Sienese architect and painter, was working in Rome until the Sack of Rome in 1527. He was taken prisoner by the Spaniards in 1527 , and was later released after painting a portrait for one of the captains. He arrived at Porto Ercole then Siena wearing only a shirt. Immediately after his arrival at Siena, Peruzzi was given the title Architetto del Pubblico from 1527-1535. During his stay in Siena, Peruzzi designed many civil and military structures . If Cataneo had been trained by Peruzzi, it would have been between these years, which correspond with the dates of the Taccuino, believed to have been completed during his architectural training.The only clear dating for the Taccuino is found in the middle of the notebook on UA 3331, which is 1533 . If the collection of drawings in the Taccuino grew over several years, it would mean that Cataneo was working on the Taccuino as part of his training as an architect with Peruzzi.

The greatest of Peruzzi's contributions while he was in Siena was probably his works on fortifications. In the first half of the Cinquecento, Siena had internal conflicts as well as wars with surrounding states. Improving the fortification of the city and the coastal region was of utmost importance. Peruzzi designed the fortifications for Maremma, Asciano and the seven bastions for the city wall of Siena. If Cataneo was trained under Peruzzi and worked closely with

entrusted the completion of commissions to the latter among which was Palazzo Francesconi (now called Palazzo Mocenni) in Siena." (Ian Cambell, Pietro Cataneo: Architetto Senese (M.A. Dissertation, 1976), 1-2.)

${ }^{12}$ Most of Peruzzi's work while he was in Siena was for the Republic. 
him, as suggested by Romagnoli and others, it would explain his deep interest and vast knowledge about fortifications.

Cataneo's training under Peruzzi most likely led to his being appointed as an architect for designing fortifications. His responsibility on site extended further than just designing fortifications. In addition to being responsible for acquiring the necessary materials and paying wages for the workers, Cataneo was also responsible for stationing the guards. In a 27 May, 1546 letter to Cataneo, there is a reference to how money should be spent on stationing the guards at Portercole.

Noi ti mandiamo scudi 60: d'oro in una lettera di Tomaso Palmieri indirizzata costi a Mess Lodovico Piccolomini quale gli e la presenterai che teli paghera subito deli quail 50: ne serrai appresso di se \& spendare in cotesta muraglia e dieci ne sarai a quelli due soldati che hanno fatta la guardia a Portercole cioe scudi $3 \ldots{ }^{13}$

Purchasing materials and paying wages to the builders are within the responsibility of an architect; however, stationing guards is outside their jurisdiction. ${ }^{14}$ Cataneo may have been of much greater importance to the Republic than just a military architect.

For all his responsibilities, Cataneo was paid a monthly salary of 22 scudi. $^{15}$ That was very similar to what was being paid to Antonio da Sangallo the Younger for his work at St. Peter's in 1536, 25 scudi per month. Although Cataneo is not recognized as a prominent architect by modern scholars, that he was being paid the same salary as an eminent architect of the time is notewworthy. In fact, Cataneo's son was granted the status of the nobility in 1592 in

\footnotetext{
${ }^{13}$ Romagnoli, Biografia Cronologica de' Bellartisti Senesi 1200-1800 Volume VII, 194.

${ }^{14}$ Cataneo may have had the knowledge of stationing guard, a he mentions how the ancient Romans planned their military camps in the first book of his second edition of the treatise published in 1567.

${ }^{15}$ Romagnoli, Biografia Cronologica de’ Bellartisti Senesi 1200-1800 Volume VII, 226.
} 
acknowledgement of his father's work for the Republic.

There are some accounts to Cataneo's personal life within the records. The birth date of Cataneo is unclear, and Romagnoli does not give any suggestions as to when he was born. One assumption that can be made concerning this is through his notebook preserved at the Gabinetto Disegni e Stampe degli Uffizi. The date of the Taccuino is believed to be around 1533. From its content, which will be discussed further in Chapter Two, we can assume that the drawings were part of his architectural training during his youth. As a result, Cataneo is generally thought to have been born in the 1510 s. $^{16}$

Romagnoli mentions his father, Jacomo di Bernardino Cataneo, also being a libraio for the contract archive. ${ }^{17}$ Cataneo also had several siblings, one of them having married Domenico Beccafumi, a Sienese painter, in 1534. Cataneo himself married in 1542 to Prudentia di M Lucca Linaiolo with a dowry of 1230 florins. ${ }^{18}$

The archival records of Cataneo after the publication of his treatise, in 1554, concern only his personal affairs. His last appearance in the records is in 1571 when he and his brother paid 120 florins to Cesare Biagini. ${ }^{19}$ Cataneo's death date is also unknown. Romagnoli estimates it to be around $1572-3 .^{20}$ This assumption is based on Cataneo's property being sold in 1574 for 400 florins to his son.

From looking at the life of Pietro Cataneo we can conclude that although modern scholars generally regard him as an insignificant figure, his practice as a military architect for the Republic of Siena was of great importance. When we consider that Peruzzi had several other

\footnotetext{
${ }^{16}$ Cambell, Pietro Cataneo: Architetto Senese, 1.

${ }^{17}$ Romagnoli, Biografia Cronologica de' Bellartisti Senesi 1200-1800 Volume VII, 178.

${ }^{18}$ Romagnoli, Biografia Cronologica de' Bellartisti Senesi 1200-1800 Volume VII, 180.

${ }^{19}$ Romagnoli, Biografia Cronologica de' Bellartisti Senesi 1200-1800 Volume VII, 238.

${ }^{20}$ Romagnoli, Biografia Cronologica de' Bellartisti Senesi 1200-1800 Volume VII, 238-239.
} 
apprentices working in his workshop in Siena, and Cataneo was selected as his successor, suggest that Cataneo was a significant figure. Unlike many of his predecessors who worked mainly on civil architecture and partly on military architecture, Cataneo was primarily associated with military architecture. Whereas many of his predecessors were idealists and theoretic concerning the design of fortified cities for their treatises, Cataneo was a practitioner and a realist. Most of the Renaissance architects were trained in other fields of art, but no evidence suggests that Cataneo was trained in other fields of art. In fact, Cataneo was well trained in mathematics, essential for designing fortifications. ${ }^{21}$ Therefore, whereas many architects would design a city based on aesthetic beauty, Cataneo's design of fortified cities are purely geometric. The knowledge of mathematics and his great experience of actually designing fortified cities prior to writing his treatise, might have influenced him to apply the grid pattern, a much more efficient approach in terms of urban planning and how to interpret the words of Vitruvius. Through experience, Cataneo must have realized that radial plans were unrealistic when it comes to planning an actual city.

${ }^{21}$ Cataneo published a treatise on mathematics, Le pratiche delle due prime matematiche, in 1567. 


\section{Chapter Two}

\section{The Taccuino and Pietro Cataneo's training as an architect}

Published in 1554, Pietro Cataneo's treatise I Quattro Primi Libri di Architettura was completed after many years of service to the Republic of Siena as a military architect, primarily as a designer of fortifications. While his treatise shows the work of a matured professional, the Taccuino, the only other surviving work by Cataneo, shows the educational process of a young apprentice. This chapter will compare the Taccuino with its source, the works of Giuliano da Sangallo and Francesco di Giorgio Martini. I will analyze the differences in interest for Cataneo and Francesco di Giorgio through the general lack of interest in copying the text by Cataneo and the layout and composition of the Taccuino.

The 106 folios are currently bound together and given the title Disegni di Ornamenti Vari di Mobili, Armature, di Architettura civile e militare, Macchine idrauliche; they are preserved at the Gabinetto Disegni e Stampe degli Uffizi. ${ }^{22}$ The only clear dating is found around the middle of the Taccuino on UA 3331(Figure 1), with a writing that states:

Pietro di Jacomo Catani descrisse et disegno in Siena addi xxiii di marzo 1533

This folio has two perspective views as well as a plan of a bastion, dominating the majority of the page. Surrounding the drawings are what appears to be examples of calligraphic practice of the alphabets and several lines of sentences. In the middle of the folio, is the above line referring to the date. It seems that this was just a part of Cataneo's practice, possibly as a way to familiarize himself with a new pen he had acquired. ${ }^{23}$

\footnotetext{
22 The title page is a later addition to the Taccuino when it was bound into a single notebook.

${ }^{23}$ Cambell, Pietro Cataneo: Architetto Senese, 13.
} 
We cannot assume that the entire Taccuino was produced in 1533. In fact, Ian Cambell points out the change in watermarks within the Taccuino found before and after UA $3331 .{ }^{24}$ It is then possible that the drawings were of at least two different volumes and was bound together in later years.

The content of the Taccuino can be separated into three parts. The first part from UA 3275 to UA 3287 consists of motifs from antique ornaments. The second part from UA 3288 to UA 3350 is about the architectural design of orders and palazzos and fortified cities. The third part from UA 3351 to UA 3381 are the drawings of the hydraulic machineries.

The most interesting feature of the Taccuino is Cataneo's general lack of interest in copying the text. All the codices by Francesco di Giorgio, which he wrote as a treatise, has both texts and illustrations. However, while Cataneo accurately copied the drawings, he disregarded the texts. The layout of some of the folios within the Taccuino does give hints of Cataneo's potential interest in copying the text. Nevertheless, the only part in the Taccuino, which has texts accompanying the illustrations, is found within the collection of fortification drawings.

The second part of the Taccuino, which deals with architectural features, is supposedly a mix of three different editions of Francesco di Giorgio Martini's Trattato di Architettura, Codice Saluzziano, Codice Ashburnham and Codice Magliabechiano. Different editions of the treatise were circulating around Italy and beyond during the Renaissance, making it difficult to guess how Cataneo managed to copy from all these different editions.

Most of the drawings of the fortifications derive from Codice Magliabechiano. When plans or other drawings of fortifications were drawn during the Renaissance, there was a tendency to dismiss the space inside the walls. This is the case for both Francesco di Giorgio and

${ }^{24}$ Cambell, Pietro Cataneo: Architetto Senese, 13. 
Cataneo in his Taccuino even though they w were both interested in the activity within the fortress. Cataneo does draw the layout of the streets in his treatise. ${ }^{25}$ For example, UA 3340 has two perspective drawings of a fortification (Figure 2). One drawing is a hexagonal fortification with multiple layers of walls and moats. The other drawing is a polygonal fortification with a sharp head on one side with two round bastions on the side surrounded by a moat and an outer wall. The hexagonal fortification on the upper part of the folio is most probably a copy of the Codice Magliabechiano tav. 290 (Figure 3). The drawing shows the outer hexagonal wall with round bastions in the apex of the hexagon and two interior hexagonal walls with polygonal bastions. In the center is a hexagonal tower. There is a moat surrounding the outer wall and between the interior walls. This is a very typical drawing seen in the works of Francesco di Giorgio. It does not illustrate how to navigate between the walls nor is there any sign of how the space inside the wall should be laid out.

However, there are a series of drawings that do show buildings within the walls of the fortification. One example is UA 3317 (Figure 4), which is a copy of Codice Magliabechiano tav. 311 (Figure 5). This drawing shows a coastal city surrounded by a wall with a square port within. The entrance to the port has a tower on each side with a wall projecting into the sea. There are also several ships depicted in the drawing. The city is drawn to be symmetrical with a wide street leading to the central building. This perspective view of a symmetrical city is often seen when Renaissance painters draw the image of an ideal city. ${ }^{26}$ What is unique about this drawing is that not only does the drawing illustrate the buildings within the fortification, but also

\footnotetext{
${ }^{25}$ Francesco di Giorgio also draws plans of cities with street patterns in his treatise, but these are not accompanied by any perspective view. They are not as well illustrated as the plans of the cities in Cataneo's treatise.

${ }^{26}$ The painting by Fra Carnevale entitled The Ideal City (c. 1480 - 1484) is an example of a drawing of a symmetrical ideal city with a colosseum, baptistery and triumphal arch.
} 
that Cataneo copied the texts, which accompany the drawings. In the Codice Magliabechiano, the text is written above the drawings, and in Cataneo's Taccuino it is the opposite; these sets of drawings which illustrate the buildings within the fortification are the only ones where Cataneo copied the text in a clean copy. ${ }^{27}$ The reason for such behavior is unknown, but the content of the writing must have had some importance to Cataneo.

I would like to compare the content of the drawings and texts for which Cataneo copied with and those that he did not. The illustrations with texts in clean copy are all in the first few folios of the collection of the fortification drawings in the Taccuino as opposed to being in the end of Codice Magliabechiano. The drawings deal with either building architecture or infrastructure on water and perspective views of coastal cities from the ocean. The description by Francesco di Giorgio for these coastal cities differs greatly from other fortified cities and gives us clues to why Cataneo decided to copy the text of one over the other.

If we look back at the hexagonal fortification on UA 3340, which is identical to tav. 290 in Codice Magliabechiano of Francesco di Giorgio, it has three layers of hexagonal wall surrounding the central tower. The central tower is also a hexagon with three levels and a pyramid on the top. The description given by Francesco di Giorgio concerning this drawing is strictly about its defense capability. ${ }^{28}$ An indication of this awareness is his mentioning the

\footnotetext{
27 The drawings with decorative alphabet and copy of the text with underlining can only be found in UA 3313 - UA 3318.

28 "Volendo edificare in piano una fortezza inespugnabile faccisi per via di fossi e muri in questa forma: in prima si segni una figura rotonda o circulare la quale si riduchi a figura esagona,[di fuore da la quale sia el fosso con cigli,] e nelli anguli [della figura si faccino] li torroni alti piedi 50. El circuito delle mura si formi sopra le linee, grosse piedi 18, fore si facci el fosso della medesima figura con cigli e sue parti dichiarate; distante da questo circuito piedi 50 si facci uno altro fosso [verso el centro] della medesima figura, largo piedi 30, dopo el quale sia uno altro circuito di mura [della medesma figura] grosso piedi 10, dove in li anguli [del quale] sieno li torrigini [quadrati] di diametro piedi 30. Dopo el quale cirquito, in distanzia di piedi 10, si facci
} 
fortification as impregnable. He begins with giving the height and width of the walls and the distance between each layer, along with the size of each of the bastions. The width of the wall and the size of the bastions decrease for the inner walls. Francesco di Giorgio concludes with describing the only street and gate into the fortification. The street, at the far right of the drawing, is emphasized as very secure. He does not give any description of its size, but mentions how it is secure and how it accommodates the need for both defense and offense.

Other drawings of fortifications follow a similar description by Francesco di Giorgio. He talks about the size of the walls and bastions and how secure the fortifications are. To mention the defensive capability, it is to be expected that we consider the military aspects to be the primary objective of designing a fortification. However, it is interesting that Cataneo chose not to copy these descriptions and merely made himself a collection of examples. The size and thickness of the walls and bastions are probably the most important element when it comes to designing fortification, since the main weapon at the time was artillery. Francesco di Giorgio emphasizes that very aspect, and if Cataneo was truly eager to learn the art and science of

uno altro fossolargo piedi 20, dopo el quale [sia] un altro cicuito di mura [della medesma forma delli altri], grosso piedi 6, con li torrigini piramidali in li anguli. Distante da questo piedi $10 \mathrm{si}$ facci uno altro fossolargo piedi 20, dopo el quale [sia] un altro cicuito di mura [della medesma forma delli altri], grosso piedi 6, con li torrigini piramidali in li anguli. Distante da questo piedi 10 si facci uno altro fosso largo piedi 20, e [dopo el quale] nel centro di questo sia una principale torre [similmente] esagona o d'altra figura più conveniente con li torrigini in li anguli soi piramidali. [E] questi circuiti e fossi debbano sempre essere più bassi uniformemente [descendendo] verso el centro, in modo che la torre del centro sia più bassa, in li fondamenti, del piano della terra di fore piedi 30. Ultimamente si facci uno muro doppio basso quasi sutterraneo da la [ditta] torre principale alla prima porta [di fore], per la quale el castellano segretamente e sicuro possi insino a essa porta andare e quella aprire e serrare secondo el bisogno, e la detta via [da quella a la torre] sia reversa [et angulata], con offese [per fianco] a maggiore utela, con [più] pori e ponti [levatoi] ed altre parti convenienti [come el prudente architetto può considerare a quella convenirsi secondo le regole preditte], come ne insegna la figura." (Francesco di Giorgio Martini, Trattati di Architettura Ingegneria e Arte Militare (Milano: Edizioni Il Polfilo, 1967) 470-471.) 
fortification, he would without a doubt, have copied the proportions of the walls and bastions. For Cataneo, however, choosing not to do so suggests that the proportions and measurements were not as important as making multiple examples.

If we look at UA 3317, which does have a text accompanying the drawings, the content of the text is very different. What is most striking is the calligraphy y Cataneo uses. The versal letter A is beautifully decorated and colored. These decorative letters are found in five other folios, all with a copy of the entire text from Codice Magliabechiano. There are other folios, which have decorative letters, but they seem more to be a practice of handwriting and calligraphy and not intended to be read later on. They are overly decorated and complicated to read. The text that follows on UA 3317 is written in neat handwriting, and there is evidence of underlining for the paragraph and underdrawing for the versal. This is clearly evidence that Cataneo prioritized the text of this drawing and was interested in the content.

The description for UA 3317 talk about how the walls surrounding the port would protect the city against a storm. ${ }^{29}$ The five other folios illustrated in a similar manner all discuss the problems that water could cause. The focus of the discussion for these folios is not the

29 " $[E t]$ apresso alla terra overo principio delli muri si facci due portoni da serrare et aprire con saracinesche, acciochè per lo flusso e reflusso del mare nel tempo delle fortune, quelle aprendo, si possi li detti porti da ogni spurcizia o arena evacuare. Si come interviene nel porto di Ancona, che per spazio di tempo le parti utili del porto si riempino e con spendio bisogna quelle evacuare, il che, essendo tale ordine dato, in tale spesa non s'incorriria. La forma e loco di queste la figura il manifesta.

[Et] a più sicurtà e perfezione del porto faccisi in mare, distante da questa intrata o bocca sua per piedi 250, uno muro di grossezza di piedi 80 come li semicirculi anteditti, [e sia] longo piedi 300, scarpato a calice in forma di angulo, ottuso [come di sopra delli corni è ditto] per resistere a l'impeto del mare.

Questo porto in due modi può essere difeso. El primo facendo in ogni estremità delli corni una grossa torre, [e] dalla una all'altra tirando catene sicondo il bisogno, per le quail non si possi né intrare né uscire senza volontà del principe, come appare disegnato.'(Francesco di Giorgio, Trattati di Architettura Ingegneria e Arte Militare, 487.) 
defense against foreign threat. In the case of the city described in UA 3317, the force of the sea was the major threat, and was to be protected by the two ports. Although the defensive capability of the city is mentioned, it is a secondary subject. Cataneo's potential interest on fortified cities located along the coast is interesting considering his later career as a military architect in the coastal cities of the Republic of Siena. He was sent there to build fortifications to protect the city against foreign threat; however, his knowledge of protection against natural forces must have been an advantage. ${ }^{30}$ In fact, one of the reasons Cataneo was hired to design the fortification might have been related to these drawings. He could have shown the Taccuino to the patron as proof of his knowledge of fortification design especially in the coastal areas. This is a plausible explanation for his sudden appearance in the archival record as the military architect for the Republic. Cataneo is not known for any prior architectural activity, thus his success as military architect for a crucial project for the Republic is an issue that can be explained only through his drawings in the Taccuino.

Another set of interesting drawings found in this second part of the Taccuino relating to water are those of the dams and weirs. UA 3292r (Figure 6) and UA 3292v (Figure 7) have a total of eighteen drawings among the two sides of the folio. Two of them are bridges and five are of city plans. The cities all have a source of water nearby or running through the city. The rest are drawings of dams and weirs,all from Francesco di Giorgio's Codice Saluzziano and not original to Cataneo. This common interest on how to acquire and maintain water within the city speak about the common issue that both Francesco di Giorgio and Cataneo were encountering. Both architects are from Siena, a city that has historically been suffering to acquire a permanent

\footnotetext{
${ }^{30}$ For example, the knowledge of how water flows and the design of the lock was certainly crucial element in the career of Leonardo da Vinci.
} 
water source. Ideas for maintaining fresh water supply were welcomed. Francesco di Giorgio designed an aqueduct and fountains for the city of Siena to enlarge their water supply. In the Codice Saluzziano, these drawings are supplemented by Francesco di Giorgio's explanation on how to build these structures and the possible damage that could result by the flow of the water. In addition, he explained how to build lakes as reservoirs of fresh water and raising fish. These explanations are not included in the Taccuino, which is a characteristic found in all the drawings Cataneo copied from the Codice Saluzziano.

Another aspect of the Taccuino, which is interesting in terms of thinking about Cataneo's intellectual development, is how the drawings are laid out in the Taccuino. UA 3296r (Figure 8) has, on the right side of the folio beginning from the top, two Latin cross church plans, three polygonal church plans and an octagonal central plan church with four polygonal churches on four sides on the bottom left. These are all found in the Codice Saluzziano tav. 21 and tav. 23. Except for the plan of the churches, UA 3296r is a sparsely filled, almost blank page. The arrangement of the drawings are identical to the layout seen in the Codice Saluzziano. One can assume that Cataneo intended to copy the texts that accompany the plans; however, no evidence of an underline could be found on the folio. Where Cataneo has writings on the folio, you can almost always find traces of underline, as was previously mentioned. Although Cataneo did copy the layout of the drawings, we can assume , he had no intention of copying the text. The majority of Cataneo's Taccuino is a collection of drawings from various editions of Francesco di Giorgio's treatise, but Cataneo rarely copied the way it was originally displayed by Francesco di Giorgio.

In UA 3298, Cataneo dew another series of Latin cross church plans. These are also 
from the Codice Saluzziano, but from three different folios. ${ }^{31}$ In addition to their being from different folios, they are also not in the order in which they are presented, making UA 3296r seem very unusual. Additionally, from UA 3300 to UA 3303 there are a series of plans, sections, perspective and elevations of palazzos and piazzas. These can all be found in Codice Saluzziano tav. 30 to tav. 34 . The church plans and the palazzo plans fill the entire folio. As opposed to the earlier folios where Cataneo would not only copy the drawings, but also the layout of the Codice Saluzziano, here he seems to be merely making collections of alternative plans. The way the Codice Saluzziano is laid out presented a great innovation on how to present illustrations in an architectural treatise. Until Francesco di Giorgio, architectural treatises rarely had illustrations and, even if they did, they would be in black and white. Francesco di Giorgio's mode of presentation, having illustrations alongside the text, enabled further understanding of the text. They were also fully colored, which makes them more attractive. Cataneo was probably learning the innovative mode of representing architectural work when he started copying in his Taccuino. When he had several such folios, he focused on making collections of design like many other sketchbooks by contemporary architects.

The content of the first part of the Taccuino is mostly from Giuliano da Sangallo. Although, I have not been able to identify the exact same motif for all the drawings, without any doubt, Cataneo had been inspired by the drawings of Giuliano da Sangallo for the first part of the Taccuino. In fact, most of the drawings derive from Giuliano da Sangallo's Taccuino Senese, a collection of 52 folios with a wide variety of content, currently preserved at the Biblioteca communale degli Intronati in Siena. Of the 52 folios, the relevant ones for comparison with the Taccuino are folios $38 \mathrm{v}$ to $45 \mathrm{r}$. These are random drawings of armory and mythical figures.

${ }^{31}$ The plans are from Codice Saluzziano tav. 18, 19, 20. 
For example, the drawing of the cherubs on the top of UA 3277 is nearly identical to that of Taccuino Senese 40v. Both cherubs have winding vines at their side. UA 3277 has a winding plant on its left whereas the 40v has an urn. However, the silhouette of the two drawings are almost identical.

Although I am confident that the source of material for the first part of the Taccuino is Giuliano da Sangallo's Taccuino Senese, we do not know how Cataneo was able to gain access to see the drawings. Giuliano da Sangallo died in Florence in 1516, which made it almost impossible for Cataneo to have known him in person. Taccuino Senese was passed on to Giuliano da Sangallo's son Francesco da Sangallo, a sculptor, who preserved it at his family house in Borgo Pinti in Florence. ${ }^{32}$ Thus, the most likely explanation is that Cataneo visited Francesco at his house in Florence and saw the Taccuino prior to 1533.

As for the content of the third part, they can most certainly be found in one of the codices of Francesco di Giorgio. They are copies of the open box machinery, which you often find with many Renaissance architect's Taccuino.

What the drawings in Cataneo's Taccuino indicate contradict the traditional interpretation of Cataneo as a military architect. First of all, Cataneo was interested in issues far beyond military architecture. He was interested in antique motifs, civil architecture and hydraulic machinery, like many other Renaissance architects. The Taccuino does show that Cataneo was interested primarily in fortification. However, if we were to assume his priority, based on what was copied to the Taccuino, we would have to think that he was more interested in matters concerning water and the city. This focus is obvious from his drawings of the dams and the fortified cities in the coastal region and the effort he made to copy the text of only this portion of

${ }^{32}$ Ulrich Middledorf, "Portraits by Francesco da Sangallo." The Art Quarterly 1(1938): 115. 
Francesco di Giorgio's treatise. Additionally, the drawings of the fortified cities with ports are placed in the beginning of Cataneo's collection of fortifications as opposed to Francesco di Giorgio's placing them at the very end, another indication of the difference in what the two architects prioritized. Cataneo is clearly a student of Francesco di Giorgio's treatise, but the focus of his interest is not necessarily the same. Among the vast collection of fortifications in Codice Magliabecchiano, Cataneo does not make copies of certain drawings. Those drawings are the fortifications planned for mountainous areas. If we think of the nature of Siena, a city built on a hill, it would be most natural for Cataneo to copy these fortifications. However, Cataneo chooses not to include them in his Taccuino. Cataneo may have worked primarily on fortifications to protect cities against foreign states; however, early in his training, clearly, although interested in fortifications, his interest was directed towards protecting the city not from military threat, but from water. 


\section{Chapter 3}

\section{Historiography of Fortified Cities}

With the invention of new artilleries, the design of fortified cities changed greatly during the Quattrocento and Cinquecento. This chapter will look at various designs of fortified cities written in architectural treatises before and after the publication of Pietro Cataneo's $I$ Quattro Primi Libri di Architettura in 1554. Understanding the use of a radial plan by Cataneo's predecessors and the military architects after him illustrates his uniqueness among his contemporaries. This understandig will support the hypothesis that Cataneo's treatise was in fact the source for Daniele Barbaro's and Andrea Palladio's translation of De architettura in 1556, which will be discussed in Chapter Four.

The concept of an ideal city was first mentioned by Plato in his book The Laws. Here he describes a circular city divided into twelve different parts. He emphasized planning a city for the population and with public areas, such as temple, market and court, all concerned with human activity within the city. Plato and Platonism was influential both in ancient Rome and the Renaissance, and elements of it can be found both in De architettura and the Italian Renaissance architectural treatises. Vitruvius' De architettura was often interpreted as describing a radial patterned city, to be further explained in Chapter Four. His urban plan had great influence on the treatises of Italian Renaissance architects, Leon Battista Alberti, Filarete and Francesco di Giorgio Martini. Many architects did not necessarily write their own architectural treatises, but were inspired by Vitruvius. Among them were Leonardo da Vinci, Fra Giocondo and Baldassare Peruzzi. Horst de la Croix assumes that, from the way De architettura and classical architecture was interpreted by the Renaissance architects, the radial plan had an aesthetic potential perfectly 
expressing the ideal Italian Renaissance city ${ }^{33}$.

Leon Battista Alberti (1404-1472) published De re aedificatoria in 1452. The treatise had more detailed explanation of how to design a city compared to De architettura. He favored a city with a circular shape like that of Vitruvius, but also provided variations according to the site, most noticeably cities built on hills and near an ocean. Alberti also explained examples of various ancient cities. ${ }^{34}$ This book was fundamental in establishing the ideal Italian Renaissance city. The architects who succeeded Alberti, Filarete, Francesco di Giorgio Martini and Pietro Cataneo, all learned from Vitruvius and Alberti. However, the way Alberti was understood by these architects, in terms of urban planning, was probably not accurate. Regarding the principal streets inside the city, Alberti preferred to keep them straight. This was one of the reasons for the misunderstanding of beliefs that having a central piazza in the city and straight streets connecting it would result in a radial street pattern. However, Alberti continued to explain that the ancients would have the supporting streets and the walls of the houses built to line up in the corner. If the supporting streets were to intersect the principal streets in radial pattern, this would not have been achieved. An ideal ancient house was rectangular and lining up a rectangular house against a radial street would not make a corner for every house. We see here that although Alberti was thinking of a grid pattern, which most ancient cities were designed to be, it was not understood in such a manner by his successors. Alexandros Ph. Lagopoulos, a modern scholar on semiotics, suggests that Alberti's ideal city is the product of influences from the urban reality, Plato, Roman

\footnotetext{
${ }^{33}$ Horst de la Croix, "Military Architecture and the Radial City Plan in Sixteenth Century Italy," The Art Bulletin Vol. 42, No. 4 (1960): 263.

${ }^{34}$ Alberti's description of how cities should be designed, especially concerning the layout of the street, can be found in chapters two and three of Book IV of De re aedificatoria.
} 
and Christian traditions. ${ }^{35}$

The first architectural treatise to include an illustration of an ideal city was Trattato d'Architettura by Filarete. The ideal city introduced in the treatise is called Sforzinda for which the treatise was dedicated, Francesco Sforza (Figure 12). Sforzinda possesses a rectangular piazza and building in the center of the city, strictly following the words of Vitruvius. Although it can be interpreted from the text that Filarete is thinking of a radial planned city, he fails to present it graphically. ${ }^{36}$ The streets that are supposed to connect the piazza in the center of the city at the gates are not illustrated. Because he followed Vitruvius and designed the piazza and the surrounding buildings rectangular, they interrupt the streets. The plan of Sforzinda shows the walls surrounding the city and the circular streets within the walls in addition to the central parts of the city.

Radial plans were first successfully drawn by Francesco di Giorgio Martini, often called the "Father of Military Architecture" in his Trattati di Architettura. ${ }^{3738}$ Some people call him the "Father of Military Architecture." "Although the cities designed by Alberti and Filarete were both somewhat fortified by the wall, they did not have a significant relationship with the military inventions. This is because firearms, such as cannons, had not become formidable weapons at their time. However, the 1494French invasion had caused great damage to all existing methods of fortification in Italy; thus effective design of fortification became a great

\footnotetext{
35 Alexandros PH Lagopoulos, "The semiotics of the Vitruvian city," Semiotica 175 (2009): 208.

36 "One street will run from every gate to the piazza in addition to a main street from each of the right angles." (Filarete, Filarete's Treatise on Architecture. Translated by John R. Spencer. (New Haven: Yale University Press, 1965), 74,75)

37 de la Croix, "Military Architecture and the Radial City Plan in Sixteenth Century Italy," 270.

${ }^{38}$ Drawings in Codice Ashburnham and Codice Saluzziano both show examples of fortified city in radial pattern.

39 de la Croix, "Military Architecture and the Radial City Plan in Sixteenth Century Italy," 270.
} 
issue. In his treatise, Francesco di Giorgio Martini explains that the strength of the fortress is not dependent on the thickness of the wall, but on the quality of the plan. One of the designs of a fortress in Codice Saluzziano is of an octagonal form. The use of octagonal plan is an indication of Vitruvius' influence. The city has gates on all sides and bastions on all vertexes. He managed to connect the gates and the central piazza by making the form of the piazza the same as the form of the entire city, departing from Vitruvius' words to use rectangular piazza and building blocks. This enabled the streets to be drawn from each side of the polygon. The method of designing the piazza and the entire city in the same polygonal form became the model for all later radial plan fortified city.

The reason for the customary interpretation of the city as a radial plan is, according to Paolo Marconi, due to the influence of cosmography. ${ }^{40}$ The intense interest in homo ad circulum, known more familiarly as the Vitruvian Man, influenced the form of the city. The Vitruvian Man, showing man as being the microcosm, is the model for the circular city. The navel is the center of the city, which takes the place of the piazza. Cesare Cesariano's drawing of the Vitruvian Man, the earliest Italian translation with illustration, had influenced the way the circle would be divided into eight, sixteen and twenty four parts. The illustrations by Cesariano will be discussed in depth in Chapter Four; however, it is worth mentioning here that this bias of the Renaissance ideology is at the basis of the misinterpretation of De architettura that continued throughout the first half of the Cinquecento.

Although the ideal street pattern in the Renaissance was to use the radial plan, it was rarely put into action. One example of a newly built city during the Renaissance is Sabbioneta. Sabbioneta, which lies near Mantua, was built by Vespasiano Gonzaga and designed by

${ }^{40}$ Lagopoulos, "The semiotics of the Vitruvian city," 243. 
Gerolamo Cattaneo and Giovan Pietro Bottaccio, both military architects. The construction began in 1554 and was completed in 1590. Although the city takes the form of a fortress, it is a composite for both civil and military purposes. The street pattern applied for this city is a grid and follows the Vitruvius' word of a rectangular piazza and building blocks. However, the streets connecting the gates with the piazza are blocked by these building blocks. This layout is to prevent an easy access to the piazza, where the primary buildings of the city would be built. One of the military strategies explained by Alberti was, for a fortified city, not to make the piazza and the gates directly connected. Connecting the two places directly would make it easy for the enemy to conquer the city. Although it was designed as a fortified city, one of the epic buildings in the city is the Teatro all'antica by Vincenzo Scamozzi. The presence of a theater in the middle of the city signifies that Vespasiano was thinking of building a civilized community in Sabbioneta. Although we do not know where the idea of the plan for Sabbioneta came from, the influence of Cataneo's recently published treatise, published just prior to construction, must be recognized.

Many of the newly built fortified cities during this time period share the same characteristics. By the latter half of the Cinquecento, the war between the states had been settled in many parts of Italy. Fortified cities were not necessarily built for military purposes. Like Sabbioneta, which has greater priority for civic life, many of the fortified cities were built with the piazza, palazzo, churches and other public buildings being the center of the city.

Those who were interested in using the radial plan were the military architects in the latter half of the Cinquecento. Until then, architects were devoted to both civil and military architecture. Leonardo da Vinci left designs of numerous weapons. Donato Bramante was hired as a military engineer for Lodovico il Moro in 1493. Baldassare Peruzzi worked as the inspector 
and designer of fortification at Siena. Michelangelo designed fortification for Florence. However, the advancement of firearms and military engineering made it impossible for a single person to know all the necessary requirements of military architecture. Giovan Battista Bellucci wrote in his treatise, Nuova invenzione di fabricar fortezze di varie forme in 1598, that in order to design a successful military architecture, experience as a soldier was essential. Architects began to specialize in either civil or military architecture. The last people to write architectural treatises concerning both fields were Cataneo and Scamozzi. Afterwards, architects only wrote about their particular field of interest. Civil architects were not interested in military architectural, as evident by Andrea Palladio in his work I quattro libri dell'architettura. Simultaneously, military architects were not interested in civil architecture.

The military architects were more concerned with the practicality than the aesthetics of architecture. They were very empirical about the design of a fortified city. Their designs were based on strengthening the defensive capability of the city, and not presenting the beauty of the architecture. On the contrary, fortification by architects in early Cinquecento would use brick and stone masonry to build bastions. The knowledge of earth being stronger than stone as building material for fortification was already known, but brick and stone were aesthetically more appealing to the architects. ${ }^{41}$ The treatises by military architects would often include calculations of the range of the cannons and other artilleries, which were never seen on plans by Cataneo. They soon found out that, in order to strengthen the fortification, the most important aspect was lines of communication within the city. Thus, the radial plan by Francesco di Giorgio Martini was very appealing to them in terms of its efficiency. However, his plan was not a perfect unity of radial plan and fortification. The plans drawn by Filarete and Francesco di

\footnotetext{
${ }^{41}$ de la Croix, "Military Architecture and the Radial City Plan in Sixteenth Century Italy," 273.
} 
Giorgio were based on a civilian point of view. The center of the city was a piazza, and the streets were generally laid out to accommodate the needs of the people living in the city. Their design was the unity of aesthetic and practical urban demand, connecting the piazza with the city gates. However, in the sense of military architects, the most important thing was establishing the communication network of the military within the city. Civilian conveniences were ignored. The design of a fortress by Bellucci shows detailed drawing of the bastions, but the design of the interior of the city is scarce. Absence of interest in civil architecture and activity is obvious. The designs of fortification by military architects were purely derived from rationality. The streets connected the piazza and the bastion, not the gate. The bastion was the key factor for both defense and offense. Thus, being able to connect the piazza, where the commander would be stationed, and the bastion was important. The radial plan allowed the commander a clear view of all the bastions to give necessary orders. The unification of the radial plan and the fortified city by military architects was purely for military efficiency.

The military architects' idea of using the radial plan in fortification came also from their interaction with architects in the first half of the Cinquecento. During that time, Rome was still guarded by an old Aurelian wall and faced potential threat of the Turkish fleet. Pope Paul III assembled people with military backgrounds as well as architects. Among the military people were, Alessandro Vitelli, Sforza Pallavicino, Gianfrancesco Montemellino, Gioulio Orsini and Mario Savorgnano. Architects assembled were Michelangelo, Antonio da Sangallo the Younger, Giovanni Magone, Francesco de Marchi, Giacomo Castriotto, Galasso Alghisi and Francesco Laparelli. Antonio da Sangallo the Younger became in charge of the design of the fortification and is mentioned in most of the military architectural treatises written in the later half of the 
Cinquecento ${ }^{42}$. The influence this event might have had on military architects can be imagined just from the fact that Giovan Battista Bellucci, Giacomo Castriotto and Francesco de Marchi, who all wrote military architectural treatises of great influence, started their career during this period in Rome. This suggests that the use of radial plans by military architects was also an influence by the architects such as Antonio da Sangallo the Younger who was still fond of using a radial plan.

The fortification designed by military architects were done mostly in their treatise. The only actual radial plan city to be built in the Cinquecento in Italy was Palmanova, located in northeastern Italy. It was built between 1593 and 1598, by the Republic of Venice for the frontier protection from the Turkish attack. Giulio Savorgnano, Bonaiuto Lorini and Vincenzo Scamozzi were responsible for the design of the city. Savorgnano and Lorini were military architects who were originally responsible for the design, but Scamozzi is believed to have made modifications to the plan. The original plan of the city seems to follow the principles of military architecture, but from the fact that it was modified by a civil architect suggests that ignoring civil activity was not approved of, even at that time. The constructed city is far from being an ideal radial city for military purposes. For example, there are a total of nine streets that stretch out from the piazza, but only three are connected with the bastions. As mentioned earlier, the streets from the piazza should connect the bastions in order to strengthen the military connection within the city, however the majority of the streets in Palmanova connect to the city gates.

It is interesting to consider that what was considered to be appropriate for building a healthy city, following the words of Vitruvius, would later be interpreted as being an efficient military strategy. Trying to accommodate civic activity within the radial street pattern always

\footnotetext{
42 de la Croix, "Military Architecture and the Radial City Plan in Sixteenth Century Italy," 278.
} 
seemed to cause problems and was not illustrated effectively. Although many errors within the De architettura were already being pointed out at that time, it seems that the architects were bound by the initial interpretation of an ideal street pattern. They seemed to try to solve the inconsistency of their interpretation of De architettura regardless of it not being possible. This obsession of the civil architects was later utilized in the works of military architects and considered the heritage left by their predecessors.

What can be understood from looking at how fortified cities were being designed by both the predecessors and successors of Cataneo is that he deviated greatly from the traditional understanding of Vitruvius in his time. The Cinquecento was a time of great evolution in warfare and, as a result, demanded many innovations in the realm of architecture. The radial plan was a result of a bias to fit the ideology of the Renaissance to the civil architects, and it was seen as the most efficient urban planning for the military architects. Whether Cataneo is recognized as a civil or a military architect, he was not designing what was considered the typical fortified city in either position. Cataneo, who I believe was not primarily concerned with the military use of a fortified city but rather was more interested in the civic activity within, was able to understand the teaching of both Vitruvius and Alberti correctly through his practice. 


\section{Chapter 4}

\section{The Change in the Interpretation of Vitruvius' Fortified City}

Various editions of Vitruvius' De architectura were published during the Renaissance. The illustrations drawn by the scholars who studied the work enabled people to understand the complicated text. Through the Quattrocento and Cinquecento the illustrations have changed greatly depending on how it was interpreted by the translators. One set of illustrations, shows great change in the plan of a fortified city. For a long time, a fortified city had been illustrated using a radial pattern, however, in 1556 Daniele Barbaro and Andrea Palladio published their translation using a grid pattern. In this chapter, by comparing the illustrations of various editions of De architectura, I will argue that Cataneo's treatise was the source for Barbaro and Palladio

Vitruvius' De architectura, the only surviving architectural text from antiquity, was the bible to most Renaissance architects. It was originally written in Latin and dedicated to Emperor Augustus. Numerous copies of the text had been made throughout the medieval era; however, it was not until 1414, when Poggio Bracciolini found a copy in the Abbey of St. Gallen in Switzerland, that the Renaissance humanists began to study the text. Ever since this 'rediscovery' by Bracciolini, numerous editions have been published, first in Latin and later in Italian. In the early Cinquecento, it was translated to other languages as well and became widely popular throughout Europe.

The De architectura found by Bracciolini did not have illustrations to support the text. However, there are places in the text where clearly an illustration was intended to accompany the content. Due to the absence of these illustrations, Renaissance scholars published various editions of De architectura with illustrations of their own. This was a great help to the readers of 
the treatise to better understand Vitruvius, since his texts were complicated and often corrupted. The parts of De architectura that deals with city planning are the last four chapters of Book I. The city planning is based on the direction of the wind. Instructions given by Vitruvius on how to draw the streets in the city has caused difficulty in interpreting the correct image. The most confusing part is perhaps the last phrase in Book I Chapter VI, which reads, "apply a gnomon to these eight divisions and thus fix the directions of the different alleys."43 It does not imply how to use the gnomon, allowing room for several interpretations.

The most widely circulating edition of De architectura, prior to that by Barbaro and Palladio, was by Cesare Cesariano. Although Cesariano's edition of De architectura became widely popular as a result of its illustrations and being translated into Italian, it lacked the quality of showing the examples of antiquity. Daniele Barbaro intended to publish a more eloquent edition of the treatise with far better illustrations with the help of Andrea Palladio. ${ }^{44}$ Progress had been made over the years to understand ancient Roman buildings, and new examples of antiquities were included. Barbaro and Palladio both studied several editions of De architectura, the Fra Giocondo edtion, Cesare Cesariano edition, Diego de Sagredo edition, and the Walther Hermann Ryff edition. Apart from FraGiocondo's edition, the illustrations of the other three editions were all from Cesariano. However, the plan of the fortified city illustrated by Palladio does not look like any of the plans seen in previous editions.

Unlike his predecessors, Palladio only illustrates a single wind diagram (Figure 13). He draws a city plan, filling an entire page (Figure 14) and, separately, an enlarged plan of the

\footnotetext{
${ }^{43}$ Polio Vitruvius, Vitruvius: On Architecture. Translated by Frank Granger (Cambridge: Harvard University Press, 1983), 31.

${ }^{44}$ Margaret Muther D'Evelyn. Venice \& Vitruvius: Reading Venice with Daniele Barbaro and Andrea Palladio (New Haven: Yale University Press, 2012), 23,24.
} 
bastion (Figure 15). It is the first time that a bastion is illustrated in Vitruvius' translation. Francesco di Giorgio Martini and Pietro Cataneo had both drawn a fortified city with bastions, but they were for their own treatise. Barbaro had focused greatly in reproducing ancient architecture in this edition; therefore, it is interesting to find that he made the city plan in a contemporary manner. Bastions are Renaissance inventions and did not exist at the time of Vitruvius. In spite of it being modern compared to other illustrations in the treatise, the inclusion of this type of city plan shows the growing interest in fortified city and the evolution in warfare itself. Cataneo had published his treatise only two years prior to the publication of this translation. This edition clearly indicates the change in the ideal city plan due to the advanced technology of artillery.

If we look at the plan, we notice that the octagon, which derives from the way of the wind, is placed in the middle of the city with streets expanding out to the city wall. The city wall is an oblong hexagonal with bastions on every vertex. The street pattern is very similar to that of Fra Giocondo; however, there is a very large piazza in the center, which is very different from that of Fra Giocondo. In Fra Giocondo's plan, the insula are all square and of the same size. Here, Palladio draws a large piazza in the middle, and the insula vary in shape and size. This type of plan is seen in the fortified cities of Pietro Cataneo's treatise I Quattro Primi Libri di Architettura (Figure 16).

In Book I, Cataneo draws eight plans of a fortified city. They are all polygonal, and three possess a small citadel within the wall and two facing the sea. Common in all these is the use of a grid pattern. All the cities have streets laid out in a grid with a large piazza in the middle and smaller piazzas distributed throughout the city. Since the streets are laid in a grid within the polygonal plan, the insula become irregularly shaped as they move away from the center of the 
city. Although all the cities illustrated by Cataneo are fortified cities, they are distinctively different from the fortified cities built later in the Cinquecento with their clear military purpose.

What is noticeable about Cataneo is that his main priority when designing the city is its civic life, evident in even how the chapters are laid out in Book I. As in other architectural treatises, he begins by talking about the necessary qualities of an architect then moves on to talk about how to select the sites for building a new city. He then goes on to explain how the streets, the piazza, and the public buildings should be distributed in the city and the different natural issues that could effect the planning of a city. In the rest of Book I are descriptions of examples of the various forms of fortified cities. None of the titles for Book I mention a single word about city walls or bastions. Of course, they are talked about in several of the chapters, and individual measurements are given for the walls and bastions of each fortified city. However, whereas later military architects devote a great deal of time on how to effectively design a bastion, as that was the key to designing an efficient fortification, Cataneo clearly is not as committed to the military aspect of the fortified city. The majority of the explanations in Book I are concerned with the proportion and aesthetics of public building.

Cataneo is far more interested in how to effectively plan the streets and public buildings in the city. Like Alberti, he begins by giving examples of how ancient cities were built. Cataneo elaborates on the ideas from Alberti to explain individual buildings. He mentions that the first thing to do when designing a fortified city is to subdivide the space inside for streets, piazzas and pomerio. The center of the city was to be left empty to build a central piazza to serve the entire citizenry. The principal streets were to be built so that they would connect the gates and the central piazza. Secondary piazzas could also be built along the principal streets. The streets and the piazzas would all meet at a right angle. Cataneo does not mention the reason for 
distributing the streets and piazzas in such a manner. However, if we think about him repeatedly mentioning that planning a city is for the convenience of its citizens, the grid pattern is the most equal and democratic way of dividing land. Therefore, surrounding the central piazza is to be constructed the palazzos of the noble, the cathedral and the academy. Other public buildings are to be built around the secondary piazzas. The principal architectures are assembled at the center and the secondary architectures are equally positioned throughout the city. As a result, all the ordinary citizens have equal access to the necessary spaces. In his treatise, he has achieved planning a very democratic city.

Another factor illustrating that the cities were not primarily for military use can be seen in the relationship between the wall and the streets. If we look at any of the plan, we notice that the street plan is independent from the wall. The streets are laid out perpendicular to the piazza and therefore do not necessarily meet the vertex. This positioning would cause a serious military problem, since the efficiency of communication and transportation of artilleries would be lost. As an architect who had served the Republic and having built fortifications for many years to fight against foreign threat, Cataneo would have known the importance of connecting the bastions and its efficiency to maximize defense. In fact, when he talks about individual cities, he explains the dimensions of each wall and bastion in detail. Therefore, Cataneo is not ignorant about the importance of the walls and bastions, but to him, they were merely elements in maintaining a peaceful city. He mentions that when building the walls, bricks should be used since they are aesthetically more pleasing. Cataneo's interest in the aesthetic quality of the city can be found throughout the treatise. To him, of utmost importance was to build a city that enabled an active civic life and that possessed an aesthetic quality.

All the characteristics that I have mentioned for Cataneo's cities can be applied to 
Palladio's illustration for Barbaro. A church and a palazzo is placed at each end of the central piazza with smaller compartments surrounding it. The streets are independent from the wall, and any relationship between the two is hard to find. Palladio, unlike Cataneo who had great military architecture experience, was probably not familiar with fortifications. Therefore, it would be understandable for him to apply one of the designs of his predecessor. However, fortified cities with bastions were an innovation that had not been illustrated in any earlier editions of Vitruvius. The only treatise circulating with a drawn fortified city were manuscripts of Francesco di Giorgio and the recently published treatise by Cataneo. Cataneo's treatise was also an ideal option for Barbaro, since Barbaro cited Alberti the most often, and Cataneo's description of a city was based on that of Alberti. Additionally, Cataneo's emphasis on civic life over the military aspect must have been appealing to Barbaro and Palladio. As explained in Chapter Three, radial pattern might have great efficiency for military purposes, but is often not concerned with the civic life.

Prior to the publication by Barbaro and Palladio, there were numerous editions of Vitruvius' De architectura published. The first edition to be published was by Giovanni Sulpizio around 1486. This was the first time that the complete edition of Vitruvius was published. It was in Latin and had no illustrations, like Vitruvius'. Although Sulpizio is known to be well educated in classical language, this edition is often considered inaccurate. However, it did mark the start of a new academic study on Vitruvius, and many of the authors of the later editions of Vitruvius do cite the work of Sulpizio.

In 1511, Fra Giocondo, or Giovanni Giocondo, published the first edition of De architectura with illustrations. It contains 136 woodcuts by Fra Giocondo, enabling the readers, for the first time, to understand the complicated text visually. This is also apparent in the title 
where he states, "M. Vitruvius per iocundum solito castigatior factus cum figuris et tabula ut iam legi et intelligi possit." ${ }^{45}$ Since Vitruvius' text was very complicated and corrupted even in Sulpizio's version, Fra Giocondo was probably very certain that this publication would be innovative. This edition by Fra Giocondo was a great success and was reprinted many times in the next decade. Not only was the inclusion of the illustrations revolutionary, but Fra Giocondo was also able to obtain alternative versions of De architectura to supplement Sulpizio's version and to correct the corrupted parts. ${ }^{46}$ The difference between Sulpizio and Fra Giocondo did not derive just from the amount of access to different manuscripts, but also their careers. Sulpizio was a humanist and rhetorician; he was not educated in architecture, thus his corrections to Vitruvius' text were mostly grammatical. Fra Giocondo, on the other hand, had great architectural experience. He served Ferdinand I of Naples as collector of inscriptions and as archaeologist and served Louis XII of France as an architect and engineer. At the time of the publishing, Fra Giocondo was working at St. Peter's with Raphael and Giuliano da Sangallo. Fra Giocondo was able to make adjustments to the text, rendering the content more understandable. Unlike many of his successors, Fra Giocondo did not make comments to the text. Therefore, we are unable to determine his intentions for the added woodcuts.

Fra Giocondo created four plates of wind diagram (Figure 17) and one plate with streets (Figure 18). The wind diagrams are very similar to those created by his successors. The circle is divided into eight divisions for each wind. However, here Fra Giocondo inserts a grid pattern into the octagon he created, unlike many of his successors who placed the streets in the

\footnotetext{
${ }^{45}$ Vitruvius, M. Vitruvius per iocundum solito castigatior factus cum figuris et tabula ut iam legi et intelligi possit, trans. Fra Giocondo (Venice: G. da Tridentino, 1511), title page.

${ }^{46}$ Lucia A. Ciapponi, "Fra Giocondo da Verona and His Edition of Vitruvius" Journal of the Warburg and Courtauld Institutes (Vol. 47 (1984)), 74-76.
} 
radial pattern, as will be explained later. The grid is laid out to extend beneath the octagon. One explanation for Fra Giocondo's use of the grid pattern is from his experience in Naples. Until then, no city had never been created using a radial pattern. It might have been discussed theoretically, but was never put into action. In addition, Fra Giocondo had the knowledge of how ancient Greek cities were built. Naples, where Fra Giocondo had worked as an archaeologist, was the oldest Greek city in Italy. The ancient city of Naples was built according to a grid pattern. Grid pattern was first created by Hippodamus of Miletus in $5^{\text {th }}$ century BC and was applied in Naples as well. Vitruvius was most probably aware of the ancient Greek cities, and if he was to describe a city in his treatise, most likely the streets would be laid out in grid pattern. Therefore, it is possible that, because Fra Giocondo was aware of how ancient Greek cities were built and believing Vitruvius to be describing such a city, he used the grid pattern.

The other possible explanation for the grid pattern is the way in which Fra Giocondo interpreted the last phrase in Book I Chapter VI. If we look at the street plan by Fra Giocondo, we notice that the streets are drawn to connect the vertex of the octagon. However, not every vertex is connected, which would create a more complex plan. The key to understanding this plan is how to understand "apply a gnomon." If we were to understand this in the way used by ancient Greek mathematicians, it would mean to draw a perpendicular line. The direction, "apply a gnomon to these eight divisions and thus fix the directions of the different alleys, ${ }^{, 47}$ would mean to draw a line perpendicular to the eight divisions. This causes a new understanding of how the streets are to be laid. However, drawing a line perpendicular to a division is still an unclear method. Looking back to the text of Fra Giocondo's edition, the original phrase for eight

\footnotetext{
${ }^{47}$ Vitruvius, M. Vitruvius per iocundum solito castigatior factus cum figuris et tabula ut iam legi et intelligi possit, 31.
} 
divisions is angulos octogoni. Therefore, the perpendicular line is to be drawn in contrast to the vertex of the octagon. These perpendicular lines would therefore connect the vertexes, forming the grid pattern as shown by Fra Giocondo.

Although Fra Giocondo's edition was widely published, his method of city planning was not adopted by his successors. Cesare Cesariano published the first Italian translation with both illustrations and commentary in 1521. Much of the text is the translation from Fra Giocondo's edition. The illustrations also seem to have been greatly inspired by Fra Giocondo, but some are original to Cesariano. The treatise was printed in Como and approximately 1,300 copies were produced and circulated. ${ }^{48}$ It became the source for translations outside of Italy, as many editions of later Vitruvius in Germany and France possess the exact same illustration as Cesariano's edition.

Cesariano, like Fra Giocondo, drew several illustrations of the wind diagram (Figure 19) and a single plan of the city (Figure 20). This city plan is clearly different from that of Fra Giocondo, but the wind diagrams also show significant differences. In Fra Giocondo's diagram, which seems to follow Vitruvius's text faithfully, the polygon inside the circle is an octagon. However, Cesariano draws two octagons making it seem like an icositragon. In addition, the vertex of the two octagons is connected with the center creating twenty-four diagonal lines and a division. Vitruvius gives the name for all twenty-four divisions; however, no mention is made to have a line connecting the divisions with the center of the circle. Cesariano's interest in radial plan is evident from the wind diagrams and is clearly depicted in the city plan.

Only a quarter of the entire city is drawn by Cesariano to illustrate the complex land

\footnotetext{
${ }^{48}$ Vitruvius, Di Lucio Vitruvio Pollione de architecturea libri dece traducti de latino in vulgare afficurati, trans. Cesare Cesariano (Como: G. da Ponte, 1521) 5.
} 
division of the city. The city is drawn within the wind diagram in great detail. It is surrounded by a wall, with towers and gates on every vertex. The city wall forms an icositragon; however, the walls do not match any of the lines drawn in the wind diagram. In the middle of every two sides of the city wall is the city gate. A street is drawn to connect the gate and the center of the city, thus forming a radial pattern. There are a total of eight radial streets. This is a very different manner of placing the street from that of Fra Giocondo.

One explanation for Cesariano's use of radial pattern is that he understood Vitruvius differently from Fra Giocondo. The way Cesariano understood the phrase "apply a gnomon" is literally placing a gnomon in the center of the circle and separating the eight divisions. This would mean that the gnomon would act as a line connecting the center and the vertex, thus creating a radial plan. However, this causes a problem as to why Cesariano ignored the illustration in Fra Giocondo's edition. One possibility of answering the question is to understand Cesariano's career.

Cesare Cesariano was born in Milan in 1483 to a Milanese court official. He trained under Bramante. Cesariano spent most of his career in Milan and the Lombardy region. Cesariano was ignorant about Rome and even Florence. This is evident in his illustrations in his edition of De architectura where many of the architectural features resemble the characteristics of northern Italy. Therefore, most likely, Cesariano had no knowledge of how ancient Greek cities were built. In addition to his possible lack of knowledge is the presence of Filarete in Milan in the previous century. Like Filarete who served the Sforza family, Cesariano worked as a military engineer for the Sforza court. Hence, most likely, Cesariano was familiar with the manuscript of Filarete's Trattato di Architettura. The ideal city Sforzinda ,illustrated by Filarete had a radial plan, as mentioned in the previous chapter. Cesariano had been exposed to this 
theoretical plan and most likely applied it to his own illustration. It would also be more reasonable to apply the radial plan when Filarete had used it in an ideal city that was dedicated to the family Cesariano was currently serving.

Although Cesariano seems to have misunderstood Vitruvius in terms of laying out the streets, he did place the radial streets so that they would not intersect with the road of the wind. The radial pattern in the wind diagram represents the road of the wind. Cesariano had added another radial line between these roads to make sure that the radial streets did not meet with the wind, keeping the city healthy. However, if we look at how the land is divided within the city wall, we begin to see that it is very different from the description of Vitruvius. According to the description of Vitruvius, the insula was to be in rectangular form. In the case of Fra Giocondo, the perpendicular lines of each vortex of the octagon form a square insula. Cesariano, on the other hand, is not able to illustrate such a city plan because of the radial streets. He fell into the same problem Filarete experienced. We see small portions of the land divided into regular shapes, but for the most part of the city, the small streets are not straight, forming irregular shapes. This may be the influence of Alberti who stated that the streets in the city should not be straight as to make it seem like a grander space than it actually is.

This illustration of Cesariano's radial city, most likely a product of misunderstanding and bias, was widely spread about Italy and Europe until the publication by Daniele Barbaro in 1556. The radial pattern illustrated by Cesariano became the ideal pattern of the city in the Renaissance not just in Italy, but throughout Europe, and which would later be used in fortified cities for military purpose.

After it was published, the Barbaro edition took the place of the Cesariano edition and became widely popular. Hence, the street pattern illustrated in the succeeding editions returned 
to grid pattern. For example, the highly influential edition by Claude Perrault uses the grid pattern (Figure 21). The illustration is closer to that of Fra Giocondo's edition. Nevertheless, the misinterpretation of Vitruvius' text, which had spread through Europe, once again returned to its appropriate understanding.

By looking at the transition of how Vitruvius' text was illustrated in terms of city planning, we come to notice that Cataneo was indeed an important figure. Fra Giocondo was undoubtedly the key figure in terms of the source for many of the architects. However, it is obvious from the case of Cesariano and many others that illustrations can differ greatly depending on how they represent the text and what the reader chose to believe to be correct. The majority of the sources that Barbaro utilized had illustrations that copied the work of Cesariano. It would have been highly possible for Palladio to illustrate a fortified city with a radial plan. However, with not only the accurate understanding of the text but also Cataneo's publication being very recent, the grid pattern was restored. Close reading of the text would assure that Vitruvius was imagining a grid street pattern. However, the modern artillery made the previous city plans inappropriate for contemporary use. The new ideal city plan needed to have a bastion attached to the wall. Cataneo was probably the first person to focus his work primarily on fortification, and his treatise, considered by many to be insignificant, had significant influence on a single illustration, which would circulate more than his own treatise.

The general recognition of Pietro Cataneo by modern scholars is that he was an insignificant military architect in the middle of the Cinquecento. However, through the study of his life and comparisons with other great architects of the Renaissance, we can arrive at a different conclusion. Understanding Cataneo through what was put down in the archival records of Siena and the Taccuino, a collection of drawings done in his youth, would change the way that 
Cataneo had been viewed as a military architect. Although the majority of the work by Cataneo was designing fortifications, this resulted from the political situation of the Republic of Siena during his residence. His interest in fortification was not for purposes of war like many of the military architects in the following century. On the contrary, he was deeply concerned with how the civic life would be carried out within the fortified city.

Therefore, I Quattro Primi Libri di Architettura may be a first of its kind to have numerous fortified cities illustrated in a single treatise, but it is distinctively different. The content of the treatise, often thought to have had no influence on contemporary architects due to its lack of appeal as a military fortification, attracted those who understood the importance of planning a fortified city where the civil and military aspects could coexist. These were the reasons why Daniele Barbaro and Andrea Palladio chose to adopt the plan of Cataneo in their translation.

Pietro Cataneo may not be widely appreciated as an individual; however, the impact he had on the illustrations of Andrea Palladio, still widely read, should not be underrated. 


\section{Bibliography}

Alberti, Leon Battista. On the Art of Building in Ten Books. Translated by Joseph Rykwert, Neil Leach and Robert Tavernor. Cambridge: The MIT Press, 1988.

Argan, Giulio C. The Renaissance City. New York: George Braziller, 1969.

Bambach, Carmen C. Drawing and Painting in the Italian Renaissance Workshop: Theory and Practice, 1300-1600. Cambridge: Cambridge University Press, 1999.

Beltramini, Maria and Caroline Elam ed. Some dgree of happiness: Studi di storia dell'architettura in onore di Howard Burns. Pisa: Scuola Normale Superiore Pisa, 2010.

Boucher, Bruce. Andrea Palladio: The Architect in His Time. New York: Abbeville Press Publishers, 2007.

Burns, Howard with Lynda Fairbairn and Bruce Boucher. Andrea Palladio 1508-1680: The portico and the farmyard. London: The Arts Council of Great Britain, 1975.

Cambell, Ian. Pietro Cataneo: Architetto Senese. M.A. Dissertation, 1976.

Carpo, Mario. Architecture in the Age of Printing: Orality, Writing, Typography, and Printed Images in the History of Architectural Theory. Translated by Sarah Benson. Cambridge: The MIT Press, 2001.

Cataneo, Pietro. I Quattro Primi Libri di Architettura di Pietro Cataneo Senese. Venice, 1554.

------------- Disegni di Ornamenti Vari di Mobili, Armature, di Architettura civile e militare, Macchine idrauliche

De La Croix, Hosrt. Military Considerations in City Planning: Fortifications. New York, George Braziller, 1972.

-_Military Architecture and the Radial City Plan in Sixteenth Century Italy." The Art Bulletin 42 (1960): 263-290.

D’Evelyn, Margaret Muther. Venice \& Vitruvius: Reading Venice with Daniele Barbaro and Andrea Palladio. New Haven: Yale University Press, 2012.

Filarete. Filarete's Treatise on Architecture. Translated by John R. Spencer. New Haven: Yale University Press, 1965

Fondazione Memofonte. 'Fondazione MemoFonte Studio Per L'Elaborazione Informatica Delle Fonti Storico-Artistiche.” Accessed February 23, 2016. 
http://www.memofonte.it/index.php.

Garin, Eugenio. Science and Civic Life in the Italian Renaissance. Translated by Peter Munz. New York: Anchor Books, 1969.

Gerbino, Anthony ed. Geometrical Objects: Architecture and the Mathematical Sciences 1400-1800. Cham: Springer, 2014.

Gille, Bertrand. Engineers of the Renaissance. Cambridge: The M.I.T. Press, 1966.

Gregory, Sharon. Vasari and the Renaissance Print. Surrey: Ashgate, 2012.

Hale, J.R. Renaissance Fortification: Art or Engineering. London: Thames and Hudson, 1977.

Hart, Vaughan and Peter Hicks ed. Paper Palaces: The Rise of the Renaissance Architectural Treatise. New Haven: Yale University Press, 1998.

Hook, Judith. Siena: A City and its History. London: Hamish Hamilton, 1979.

Kanerva, Liisa. Between Science and Drawings: Renaissance Architects on Vitruvius's Educational Ideas. Helsink, Finland: Annales Academiae Scientiarum Fennicae, 2006.

Kent, William Winthrop. The Life and Works of Baldassare Peruzzi of Siena. New York: Architectural Book Publishing, 1925.

Lotz, Wolfgang. Studies in Italian Renaissance Architecture. Cambridge: The MIT Press, 1977.

Mack, Charles R. Pienza: The Creation of a Renaissance City. Ithaca: Cornell University Press, 1987.

Milanesi, Gaetano. Sulla Storia dell'Arte Toscana. Soest: Davaco Publishers, 1973.

Middeldorf, Ulrich. "Portraits by Francesco da Sangallo." The Art Quarterly 1(1938): 109-138.

Nevola, Fabrizio. Siena: Constructing the Renaissance City. New Haven: Yale University Press, 2007.

Palladio, Andrea. The Four Books On Architecture. Translated by Robert Tavernor and Richard Schofield. Cambridge: The MIT Press, 1997.

Pearson, Caspar. Humanism and the Urban World: Leon Battista Alberti and the Renaissance City. Pennsylvania: The Pennsylvania State University Press, 2011.

Pepper, Simon and Nicholas Adams. Firearms \& Fortifications: Military Architecture and Siege Warfare in Sixteenth-Century Siena. Chicago: University of Chicago Press, 1986.

Pollak, Martha D. Military Architecture, Cartography and the Representation of the Early Modern European City: A Checklist of Treatises on Fortification in the Newberry Library. Chicago: The Newberry Library, 1991. 
Romagnoli, Ettore. Biografia Cronologica de' Bellartisti Senesi 1200-1800 Volume VII. Firenze: Edizioni S.P.E.S, 1976.

Rosenau, Helen. The Ideal City: In its Architectural Evolution. Boston: Boston Book \& Art Shop, 1959.

Rybczynski, Witold. The Perfect House: A Journey with the Renaissance Master Andrea Palladio. New York: Scribner, 2002.

Smith, Timothy B. and Judith B. Steinhoff ed. Art as Politics in Late Medieval and Renaissance Siena. Surrey: Ashgate, 2012.

Tafuri, Manfredo. Interpreting the Renaissance: Princes, Cities, Architects. Translated by Daniel Sherer. New Haven: Yale University Press, 2006.

Thomas, Anabel. The Painter's Practice in Renaissance Tuscany. Cambridge: Cambridge University Press, 1995.

Vasari, Giorgio. Lives of the Painters, Sculptors and Architects. Translated by Gaston du C. de Vere. New York: Alfred A. Knopf, 1996.

Vitruvius, Polio. Vitruvius: On Architecture. Translated by Frank Granger. Cambridge: Harvard University Press, 1983.

-----------M. Vitruvius per iocundum solito castigatior factus cum figuris et tabula ut iam legi et intelligi posit. Translated by Fra Giocondo. Venice: G. da Tridentino, 1511.

---Di Lucio Vitruvio Pollione de architecturea libri dece traducti de latino in vulgare

afficurati. Translated by Cesare Cesariano. Como: G. da Ponte, 1521.

- I dieci libri dell'architettura di M. Vitruvio tradutti et commentati da monsignor Barbaro Eletto Patriarca D'Aquileggia. Translated by Daniele Barbaro and Andrea Palladio. Venice: F. Marcoloini, 1556.

----------- Les dix livres d'architecture de Vitruve. Translated by Claude Perrault. Paris: J. B. Coignard, 1673.

Weller, Allen Stuart. Francesco di Giorgio 1439-1501. Chicago: The University of Chicago Press, 1943.

Wittkower, Rudolf. Architectural Principles in the Age of Humanism. London: Alec Tiranti, 1952. 


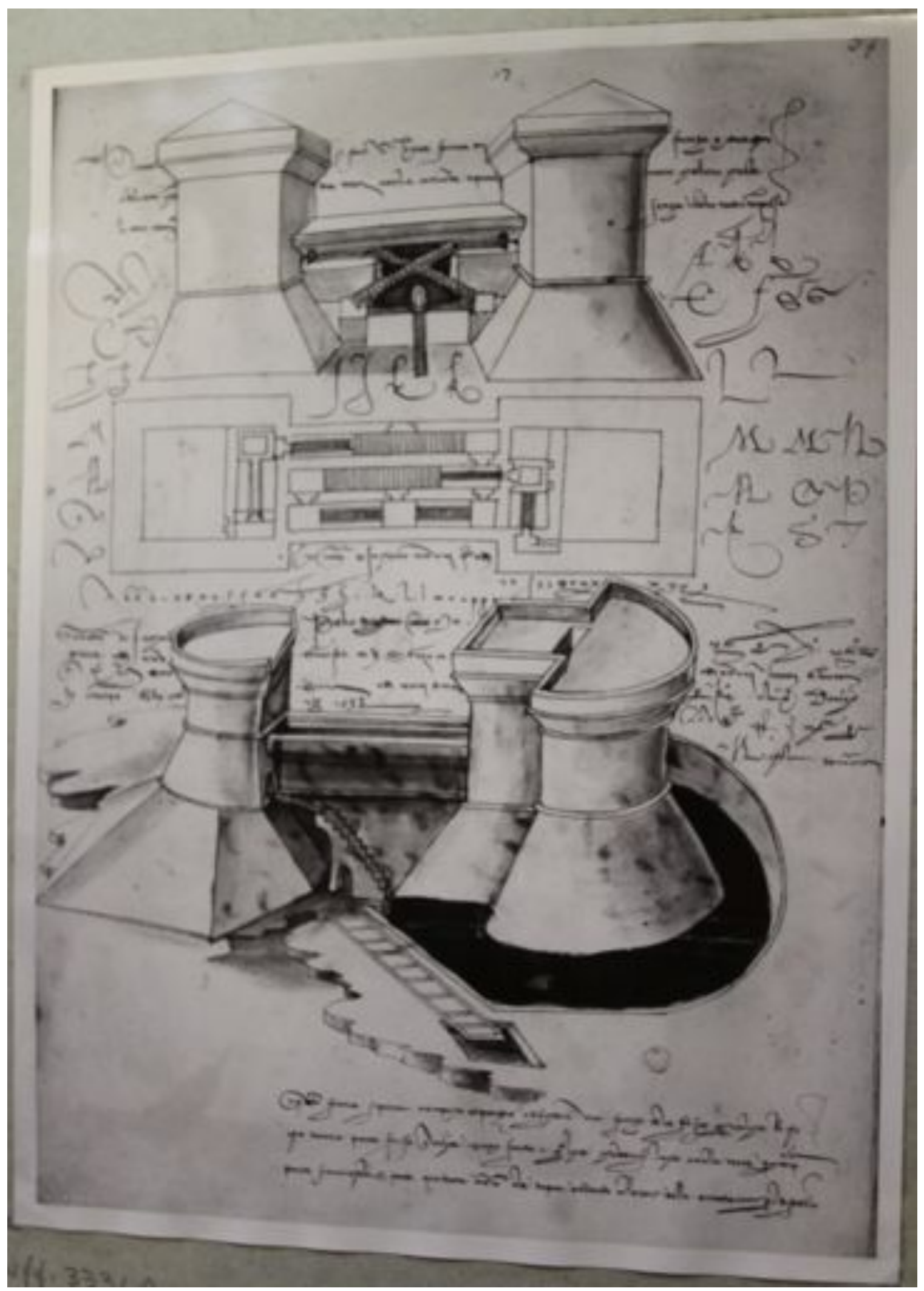

Figure 1 Pietro di Jacomo Catani descrisse et disegno in Siena addi xxiii di marzo 1533

Source: Gabinetto Disegni e Stampe degli Uffizi UA 3331 


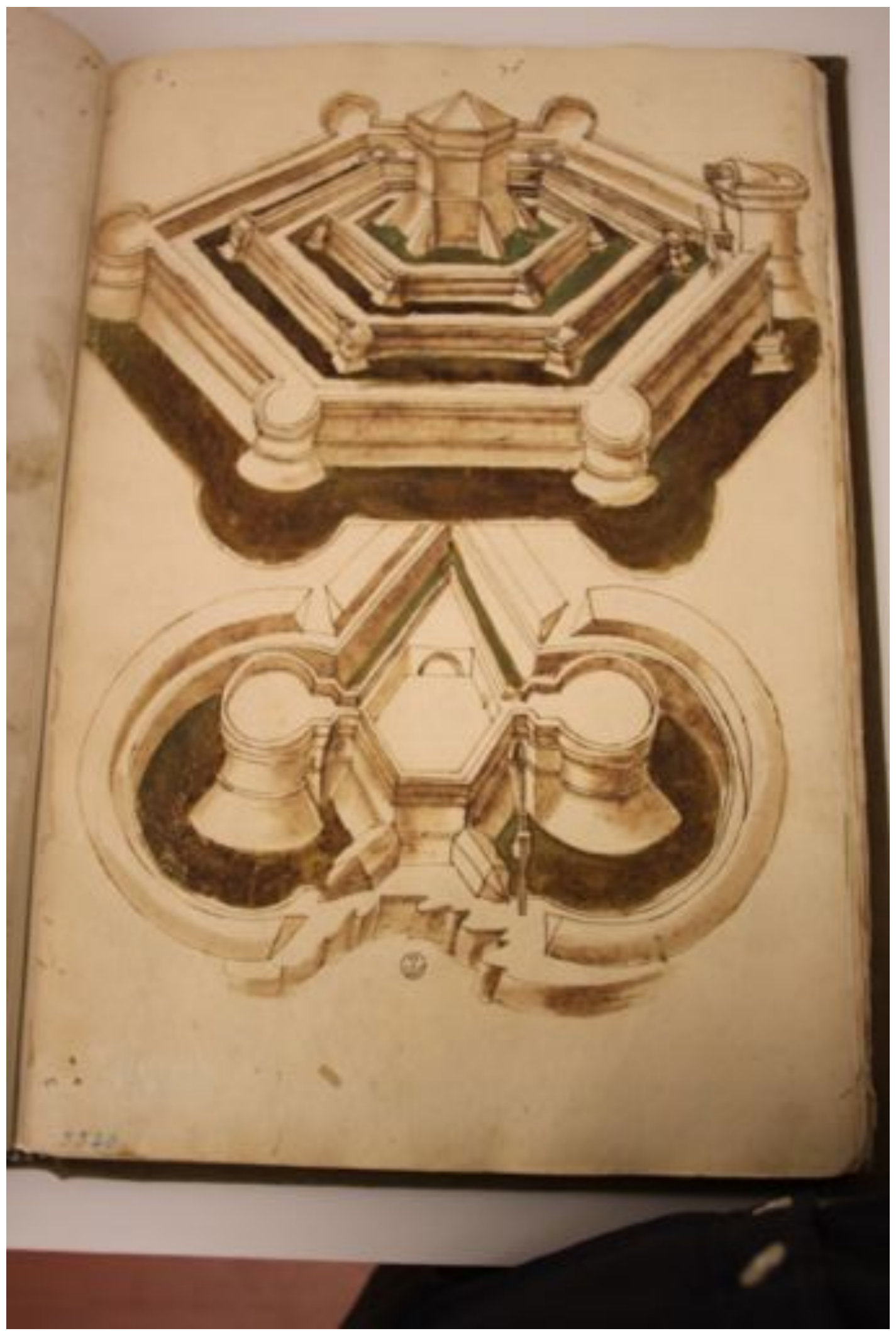

Figure 2 Perspective drawing of a hexagonal fortification by Cataneo in his Taccuino Source: Gabinetto Disegni e Stampe degli Uffizi UA 3340 


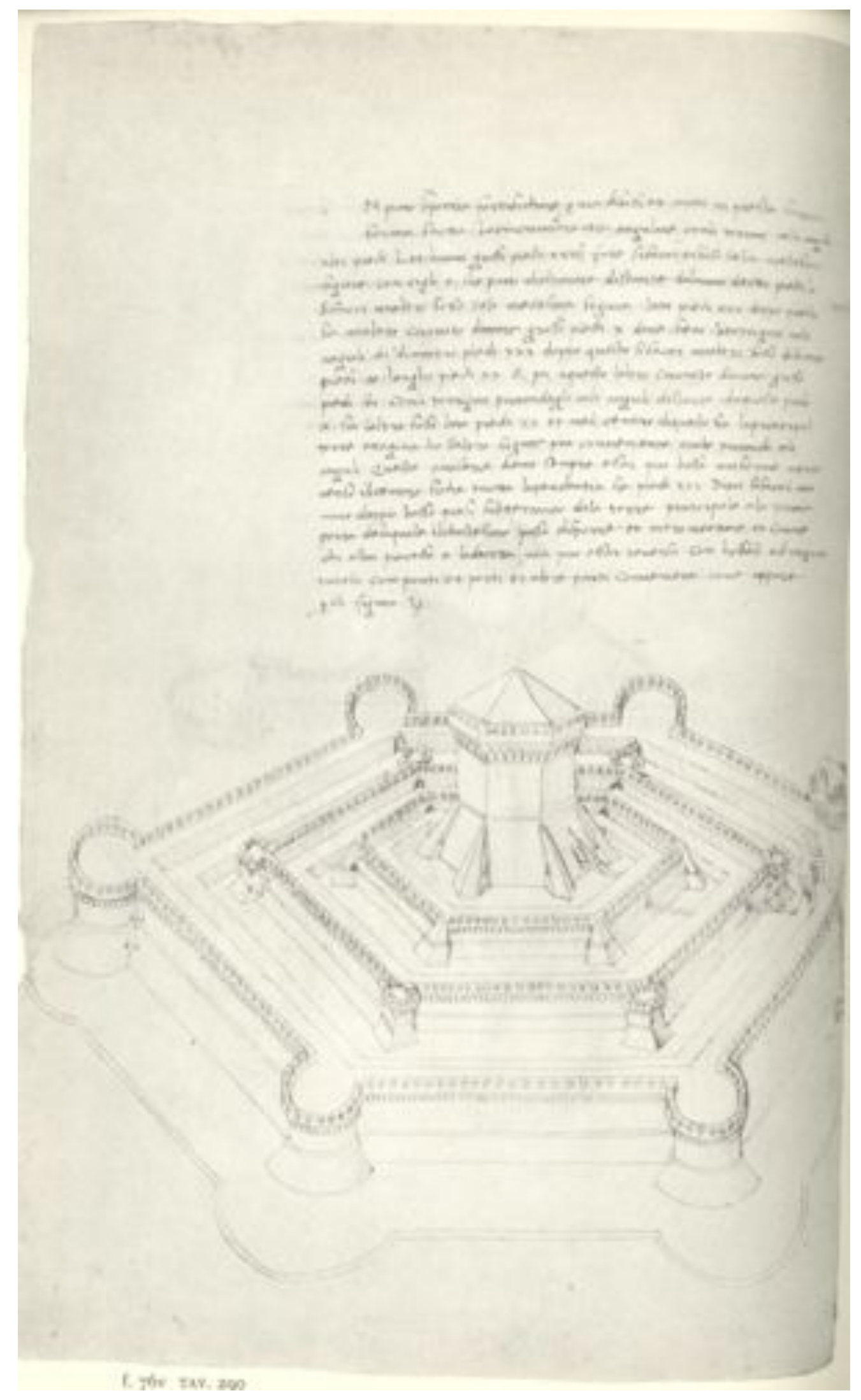

Figure 3 Perspective drawing of a hexagonal fortification by Francesco di Giorgio Martini in Codice Magliabechiano

Source: Codice Magliabechiano tav. 290 


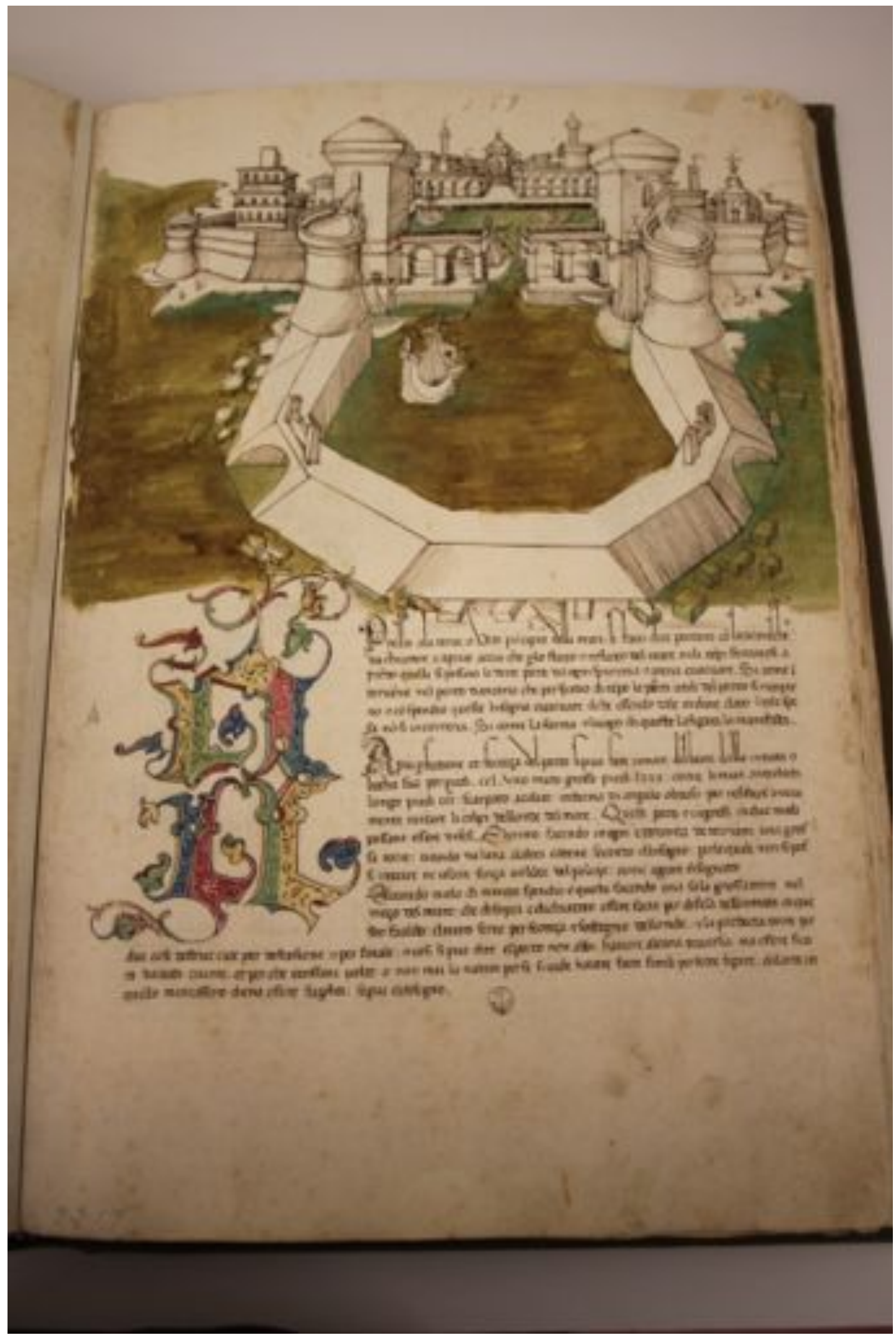

Figure 4 Perspective drawing of a coastal city with a port by Cataneo in his Taccuino Source: Gabinetto Disegni e Stampe degli Uffizi UA 3317 


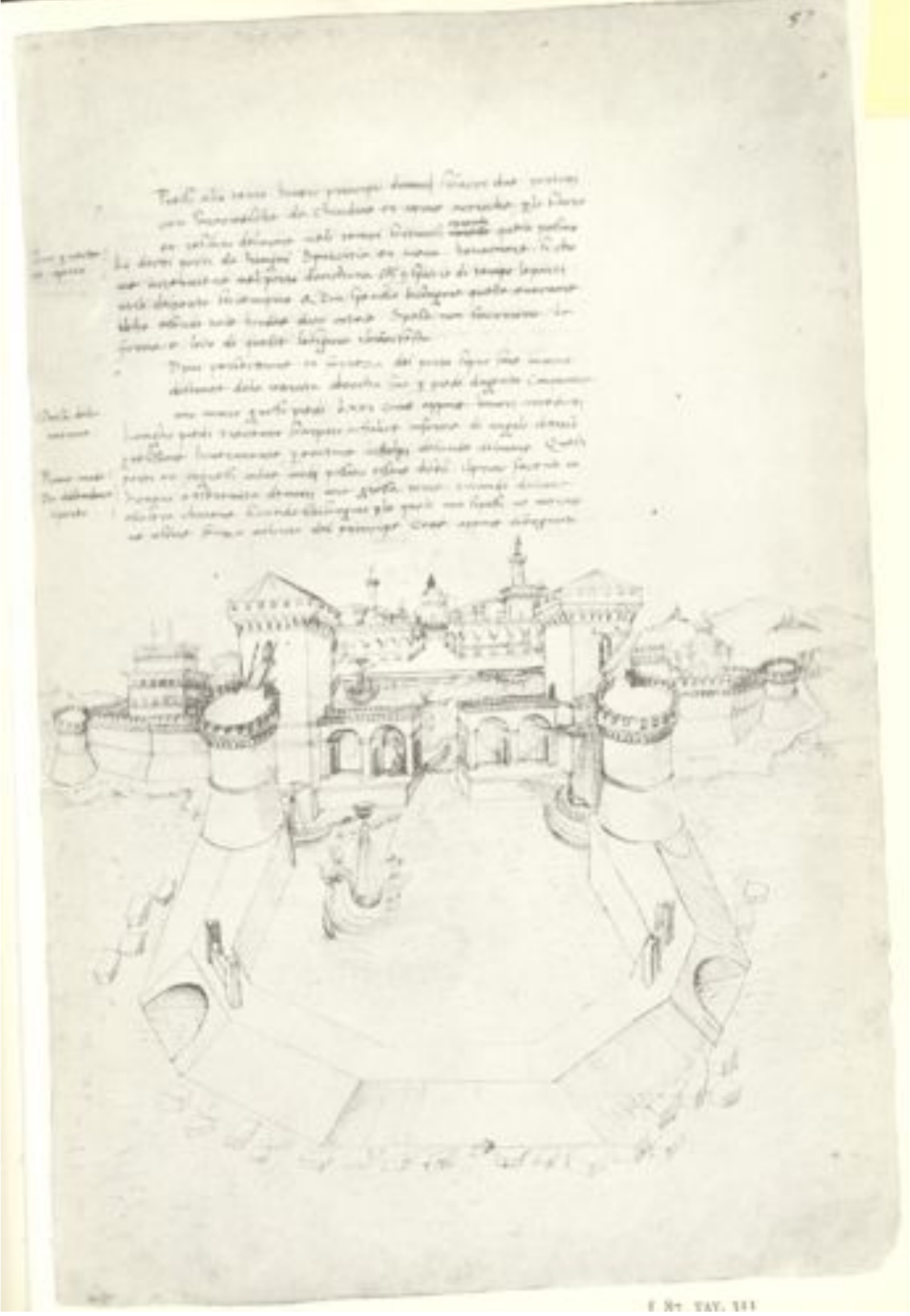

Figure 5 Perspective drawing of a coastal city with a port by Francesco di Giorgio Martini in Codice Magliabechiano

Source: Codice Magliabechiano tav. 311 


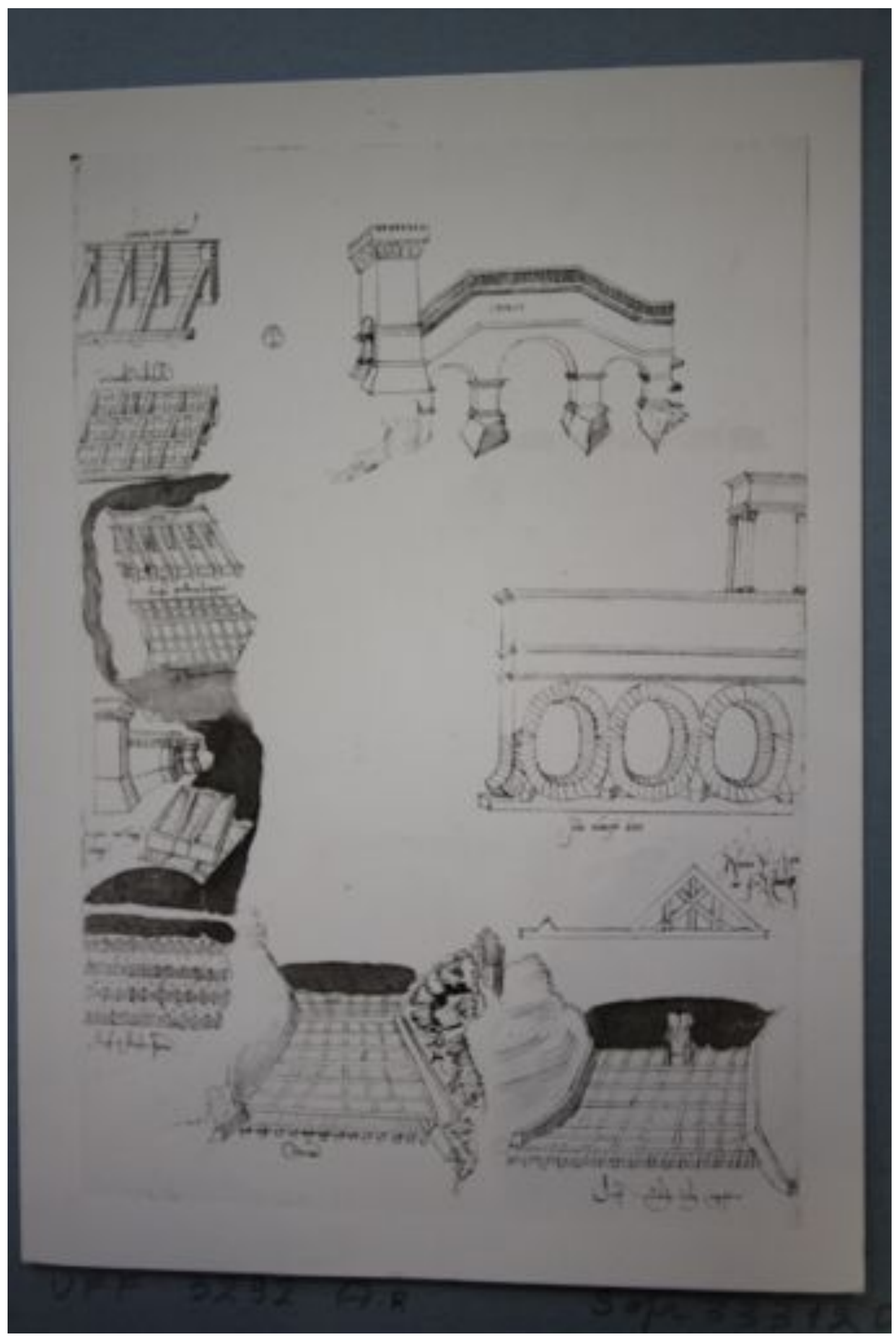

Fgure 6 Drawings of dams and weirs by Cataneo in his Taccuino Source: Gabinetto Disegni e Stampe degli Uffizi UA 3292 v 


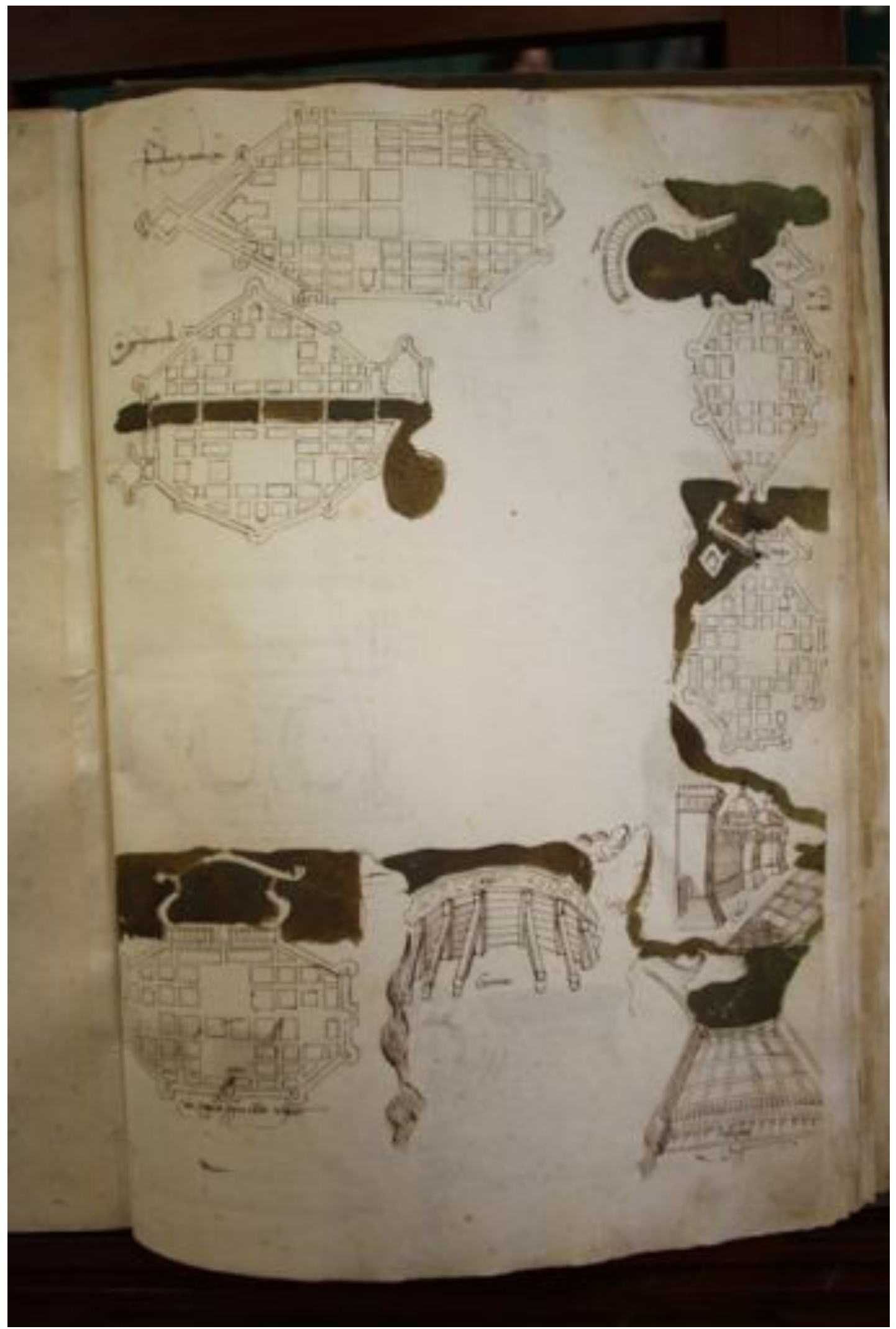

Fgure 7 Drawings of dams and weirs by Cataneo in his Taccuino Source: Gabinetto Disegni e Stampe degli Uffizi UA 3292 r 


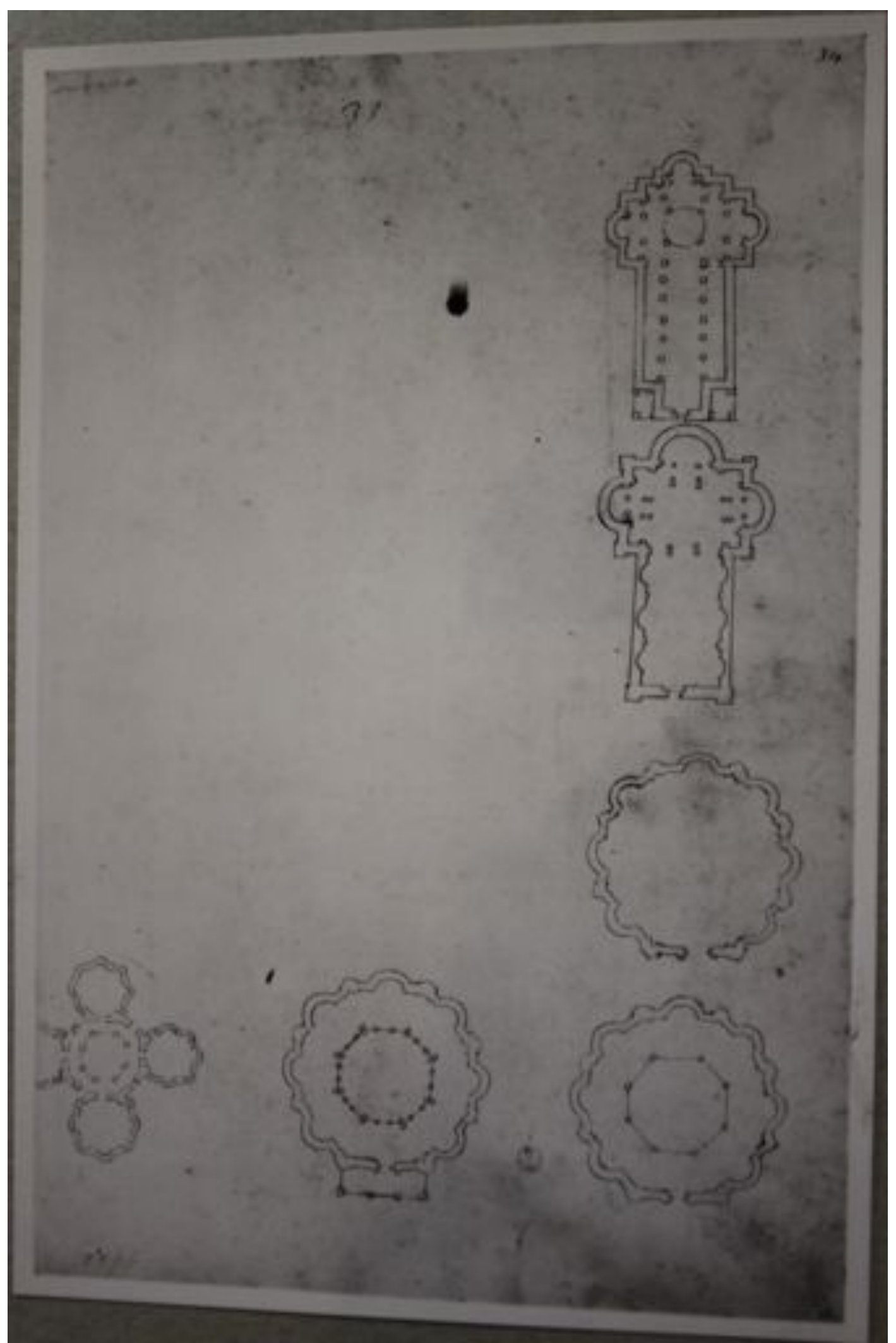

Figure 8 Drawings of church plans by Cataneo in his Taccuino Source: Gabinetto Disegni e Stampe degli Uffizi UA 3296 r 


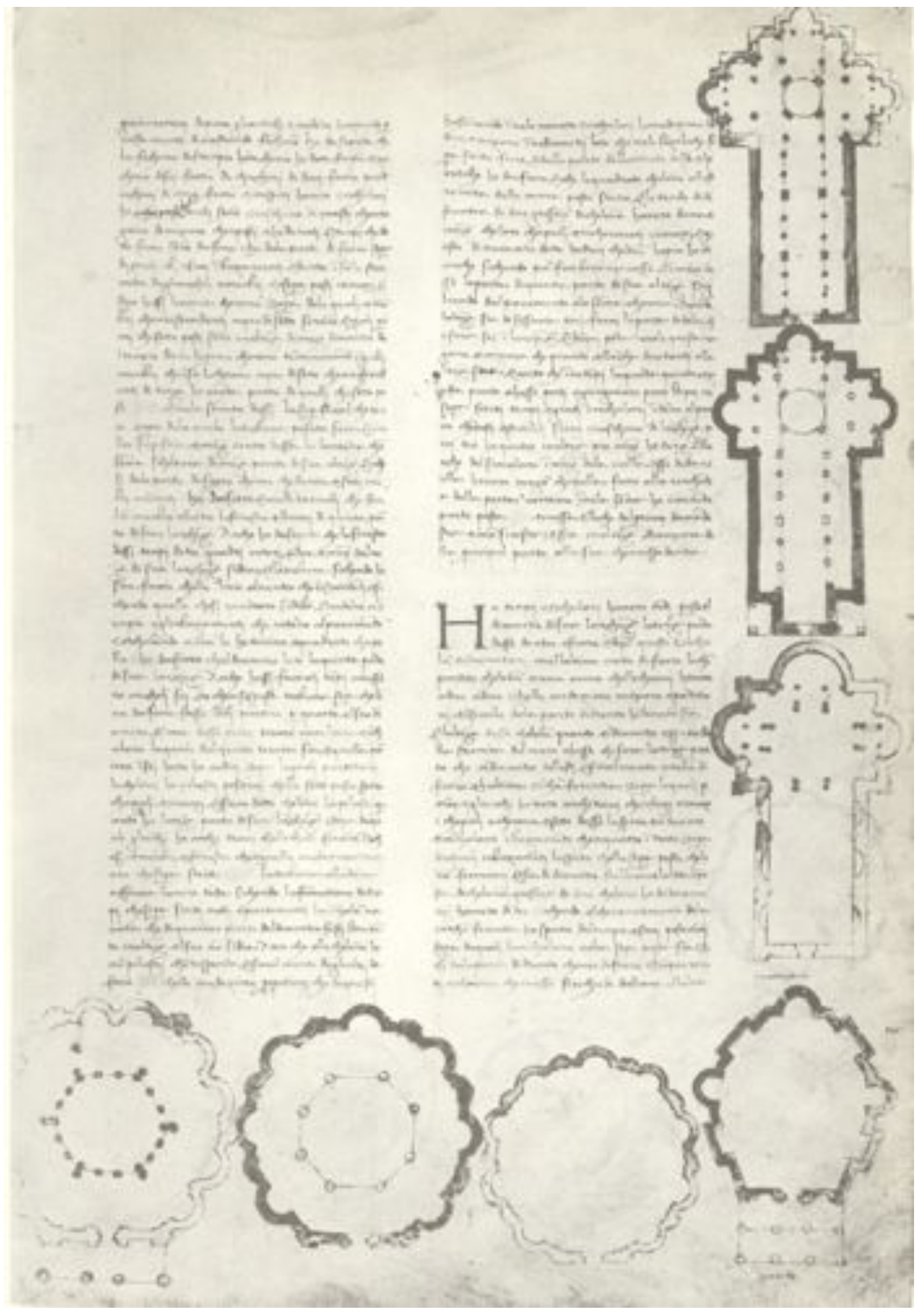

Figure 9 Drawings of church plans by Francesco di Giorgio Martini in Codice Magliabechiano Source: Codice Saluzziano tav. 21 


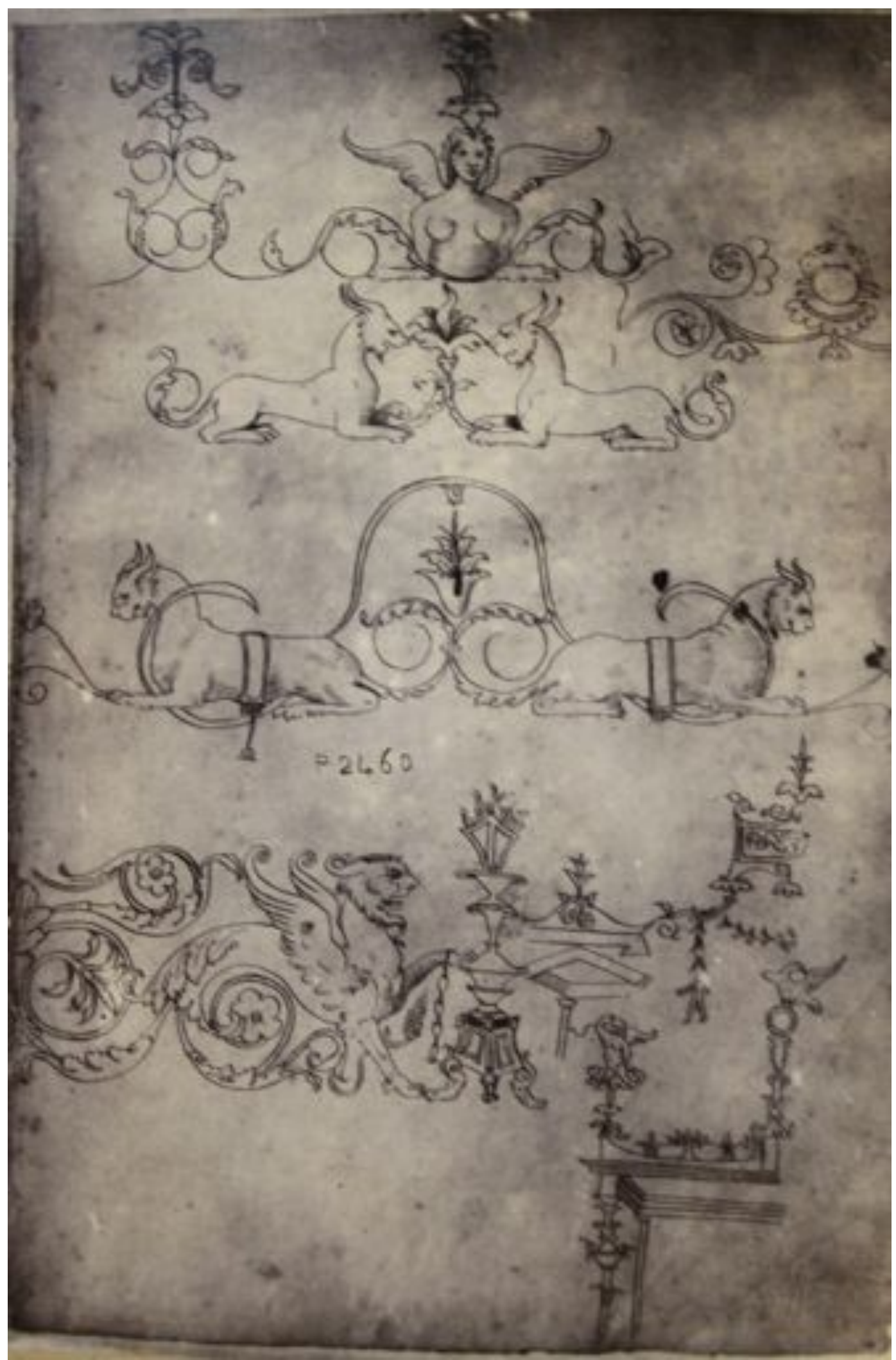

Figure 10 Drawings of the cherub by Cataneo in his Taccuino

Source: Gabinetto Disegni e Stampe degli Uffizi UA 3277 


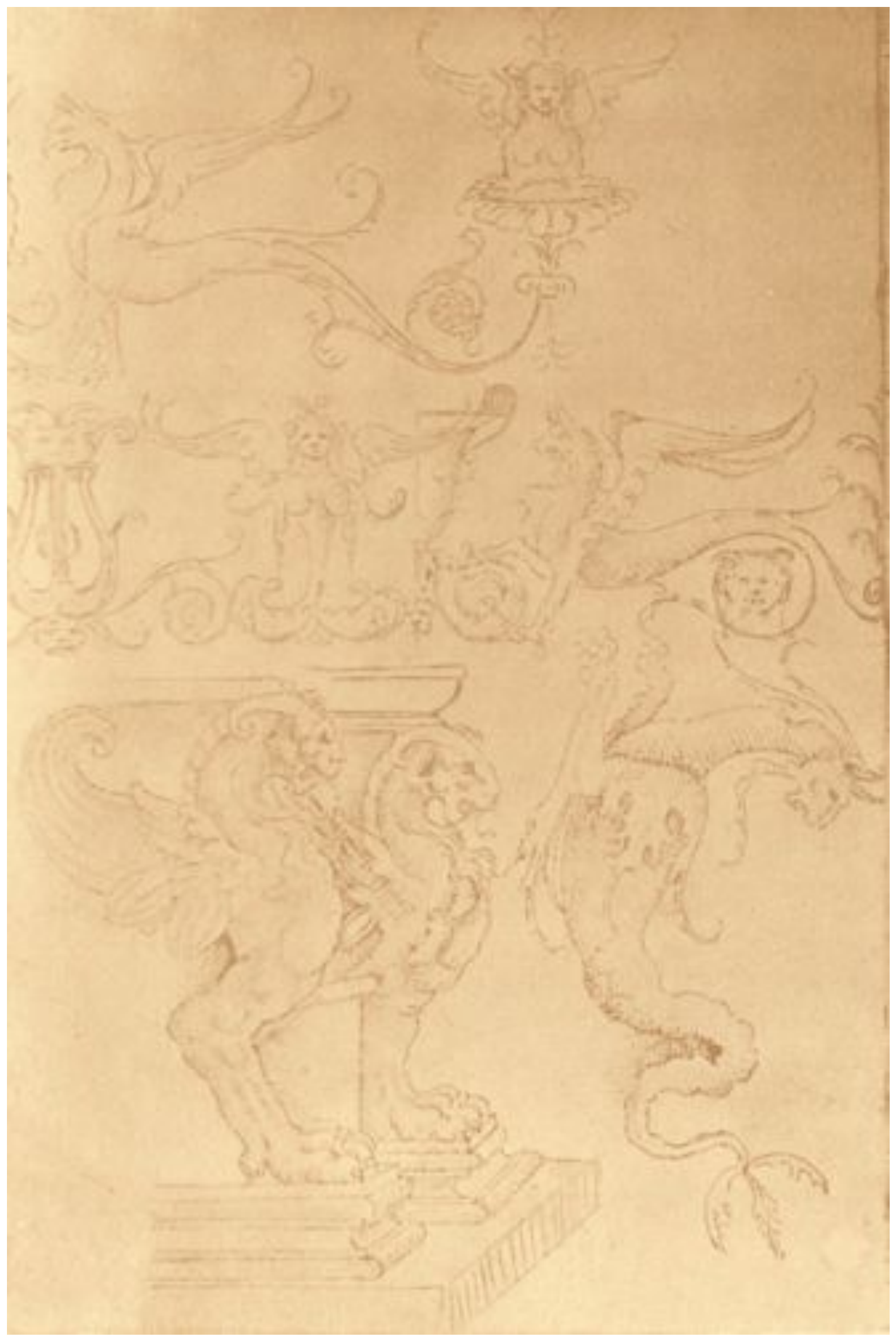

Figure 11 Drawings of the cherub by Giuliano da Sangallo in Taccuino Senese Source: Taccuino Senese 40v 
Sopue $d$

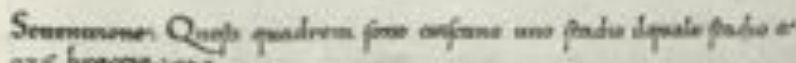

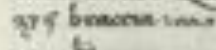

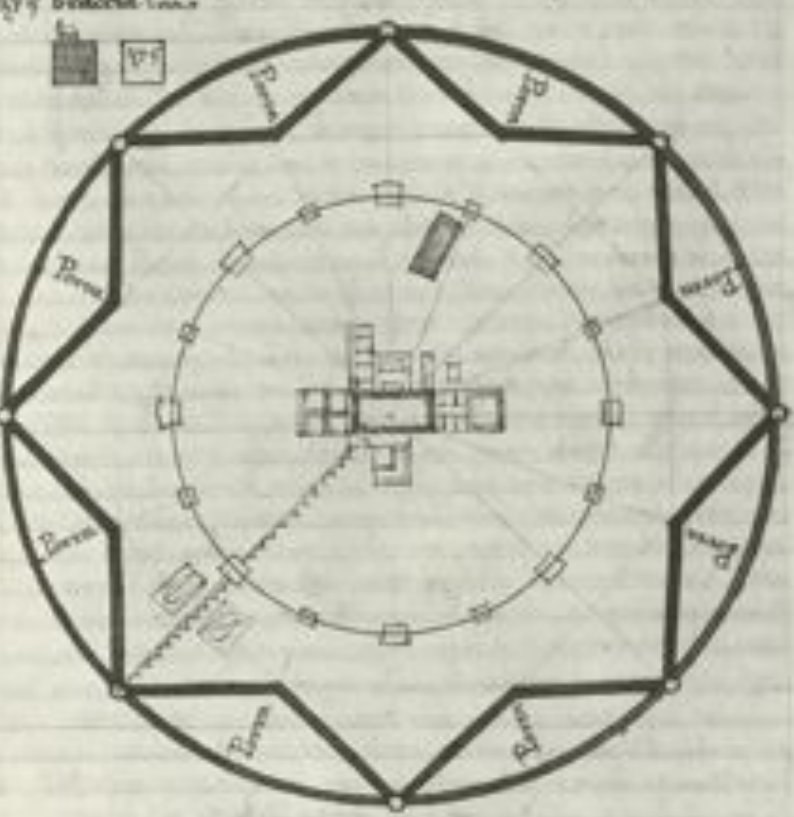

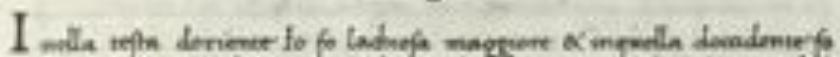

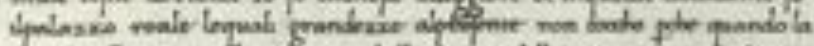

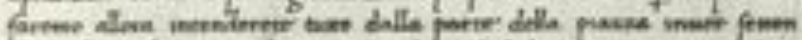

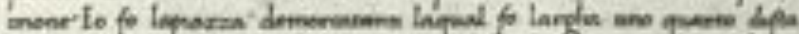

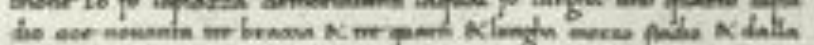

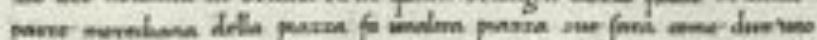

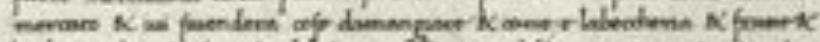

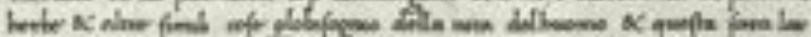

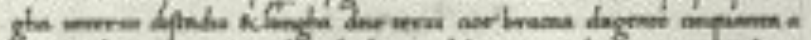

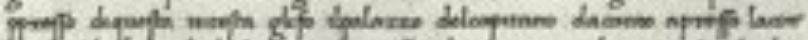

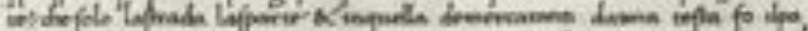

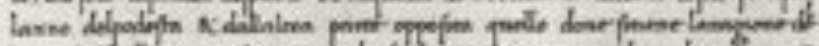

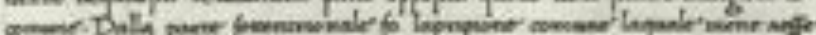

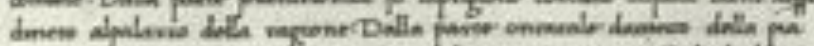

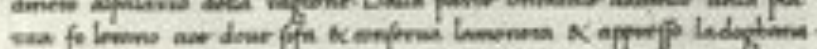

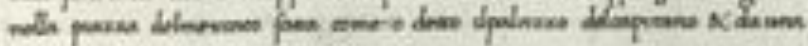
Luderpourer dello

Figure 12 The city of Sforzinda by Filarete

Source: Trattato d'Architettura 


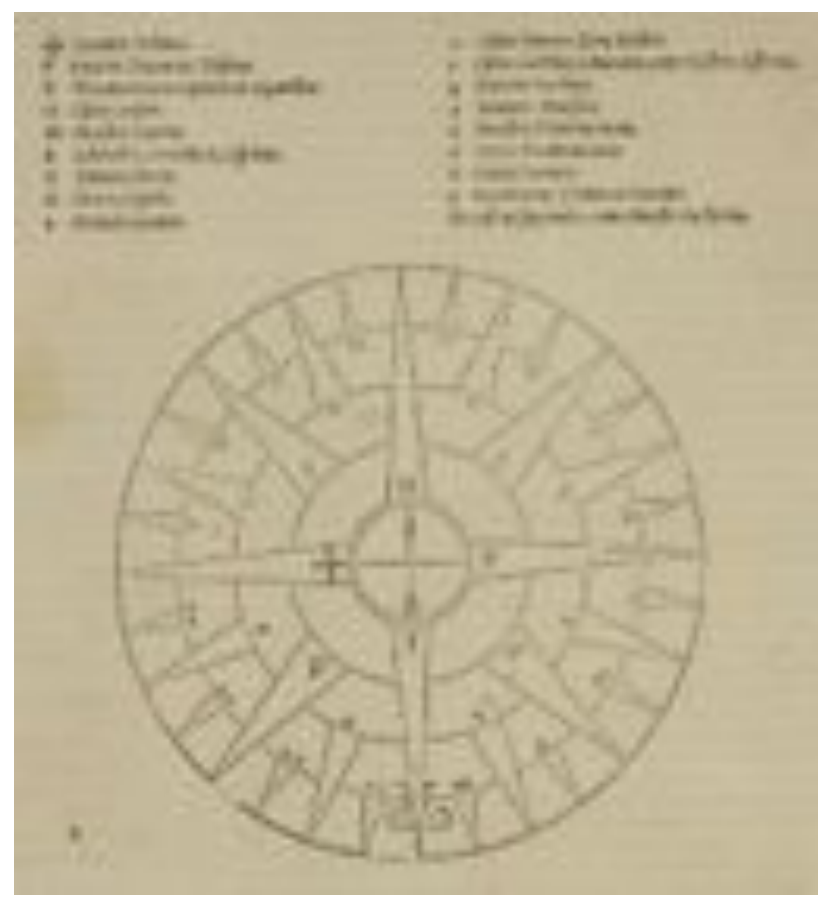

Figure 13 Wind diagram by Palladio

Source: I dieci libri dell'architettura di M. Vitruvio tradutti et commentati da monsignor Barbaro Eletto Patriarca D’Aquileggia. 35. 


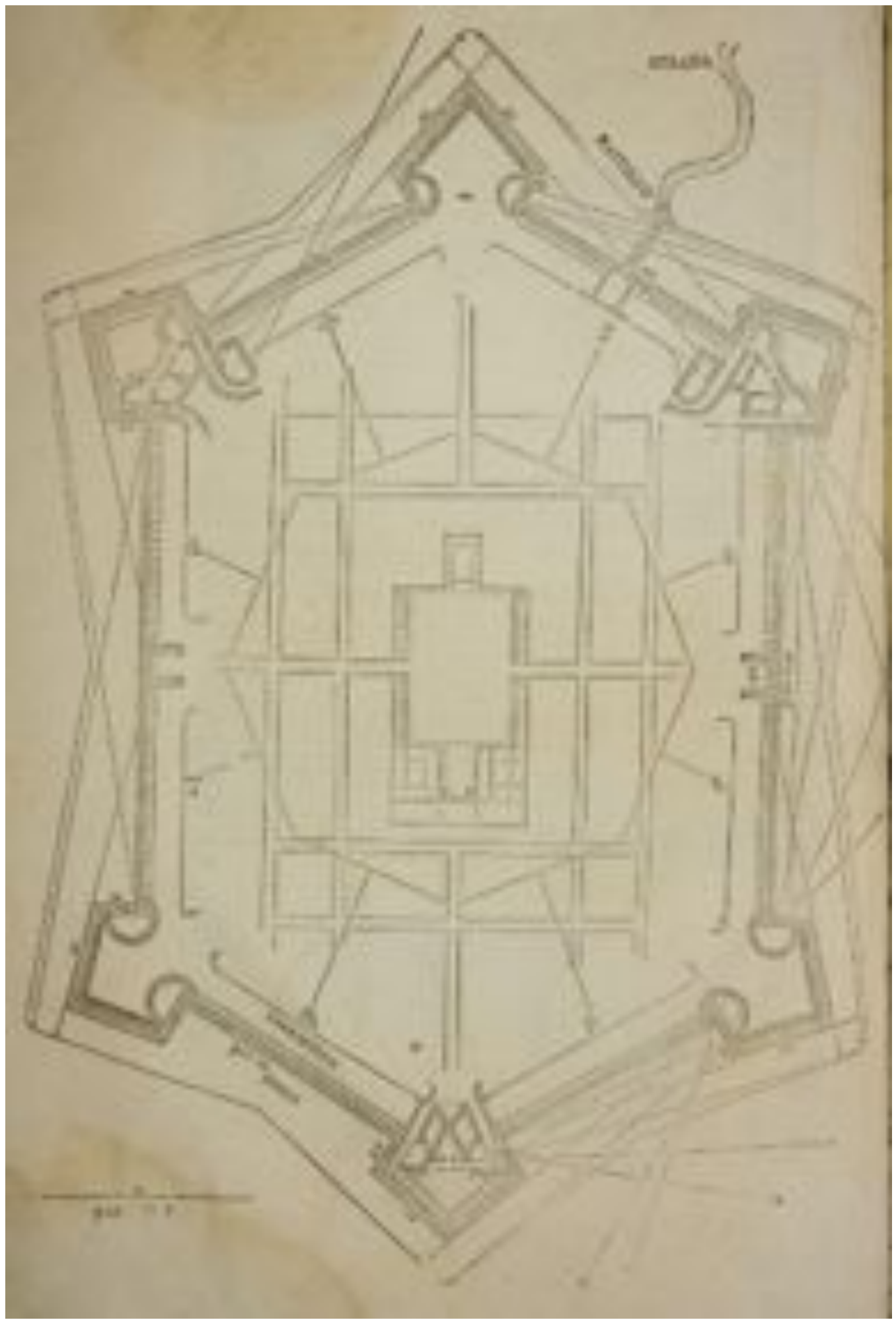

Figure 14 Plan of fortified city by Palladio based on Vtiruvius' De architettura

Source: I dieci libri dell'architettura di M. Vitruvio tradutti et commentati da monsignor Barbaro Eletto Patriarca D'Aquileggia. 38. 


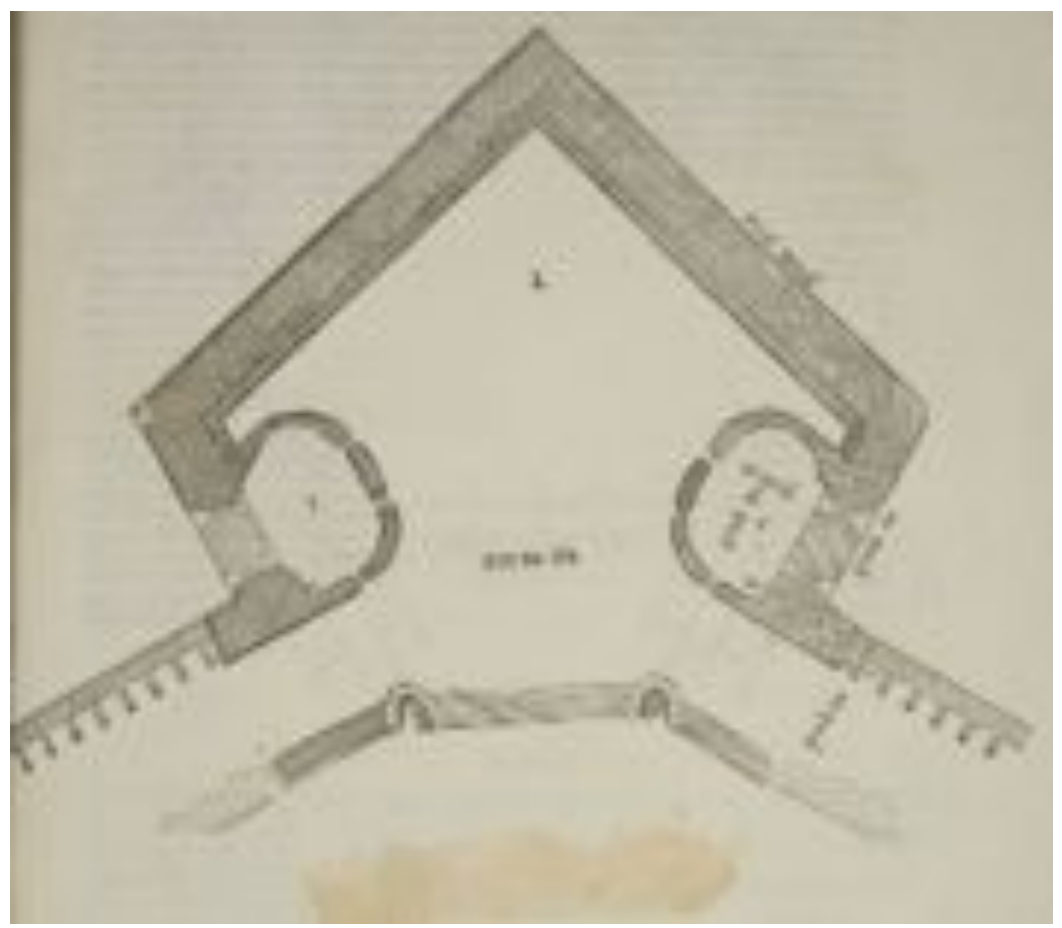

Figure 15 Detail plan of the bastion for the fortified city by Palladio

Source: I dieci libri dell'architettura di M. Vitruvio tradutti et commentati da monsignor Barbaro Eletto Patriarca D’Aquileggia. 39.

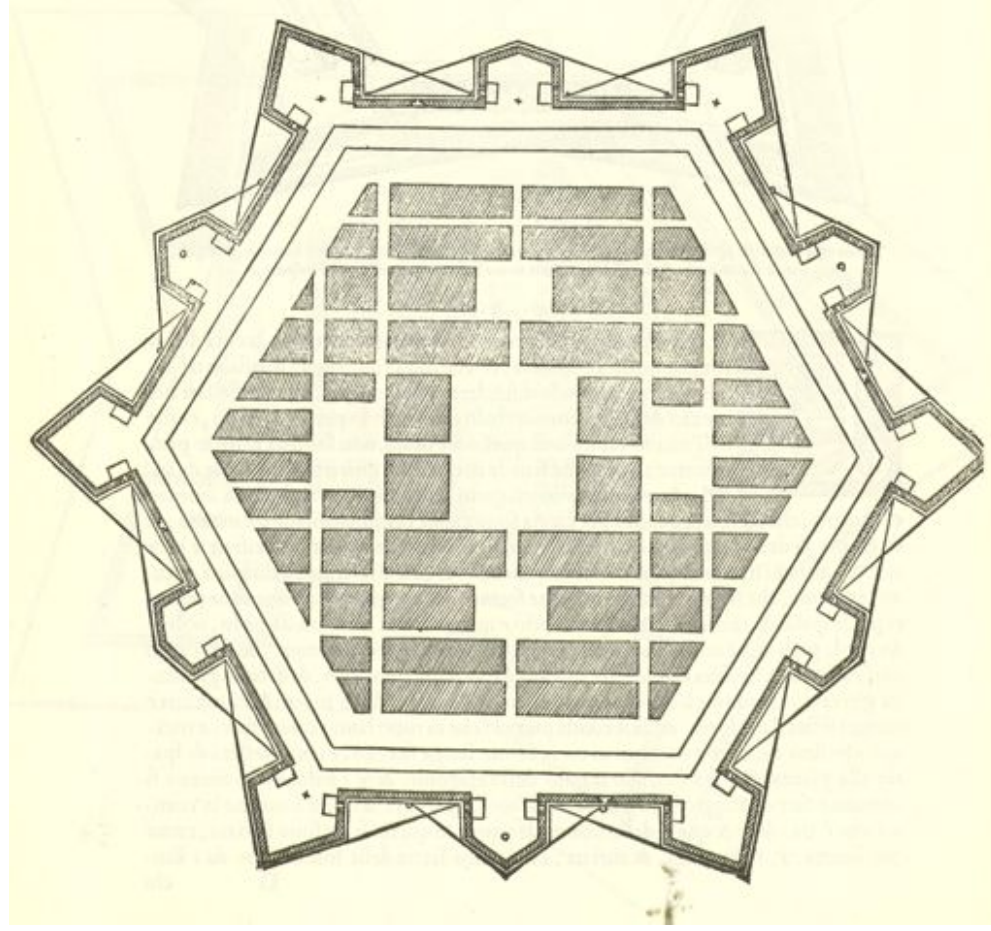

Figure 16 Example of a fortified city by Cataneo in I Quattro Primi Libri di Architettura Source: I Quattro Primi Libri di Architettura, 13v. 


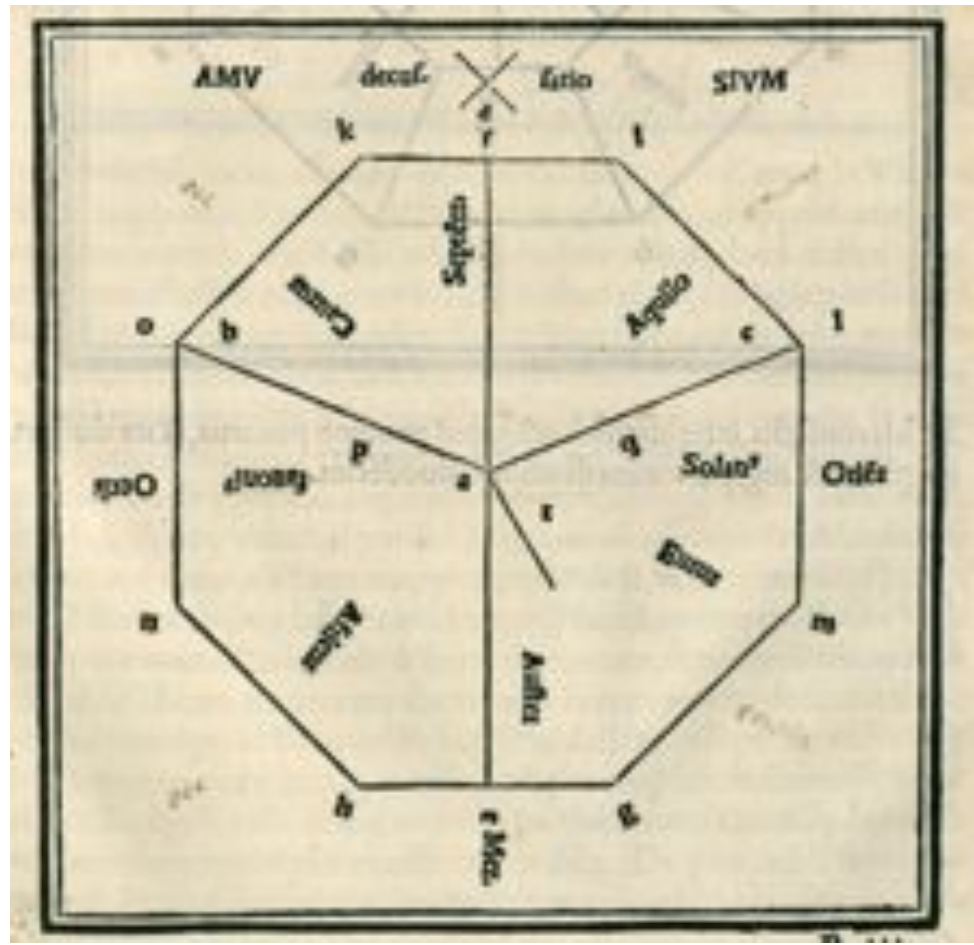

Figure 17 Wind diagram by Fra Giocondo

Source: M. Vitruvius per iocundum solito castigatior factus cum figuris et tabula ut iam legi et intelligi posit, 11r.

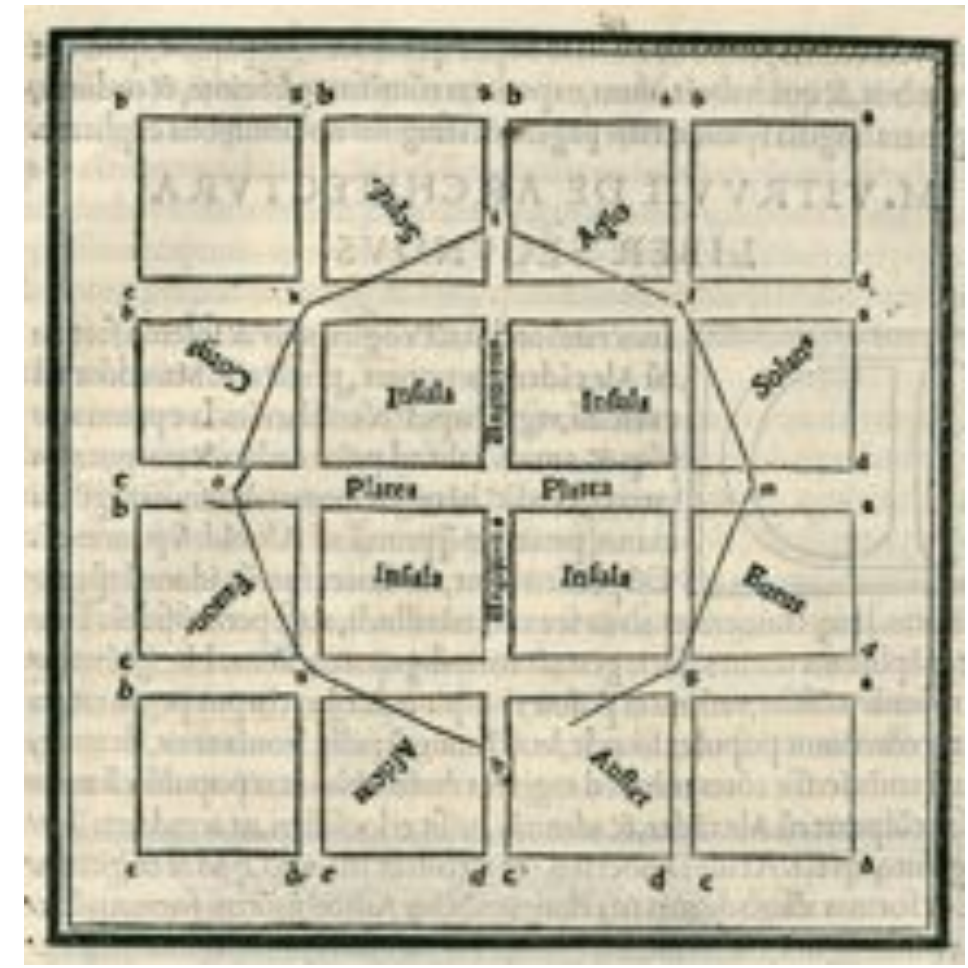

Figure 18 Street plan by Fra Gicondo

Source: M. Vitruvius per iocundum solito castigatior factus cum figuris et tabula ut iam legi et intelligi posit, $12 \mathrm{r}$. 


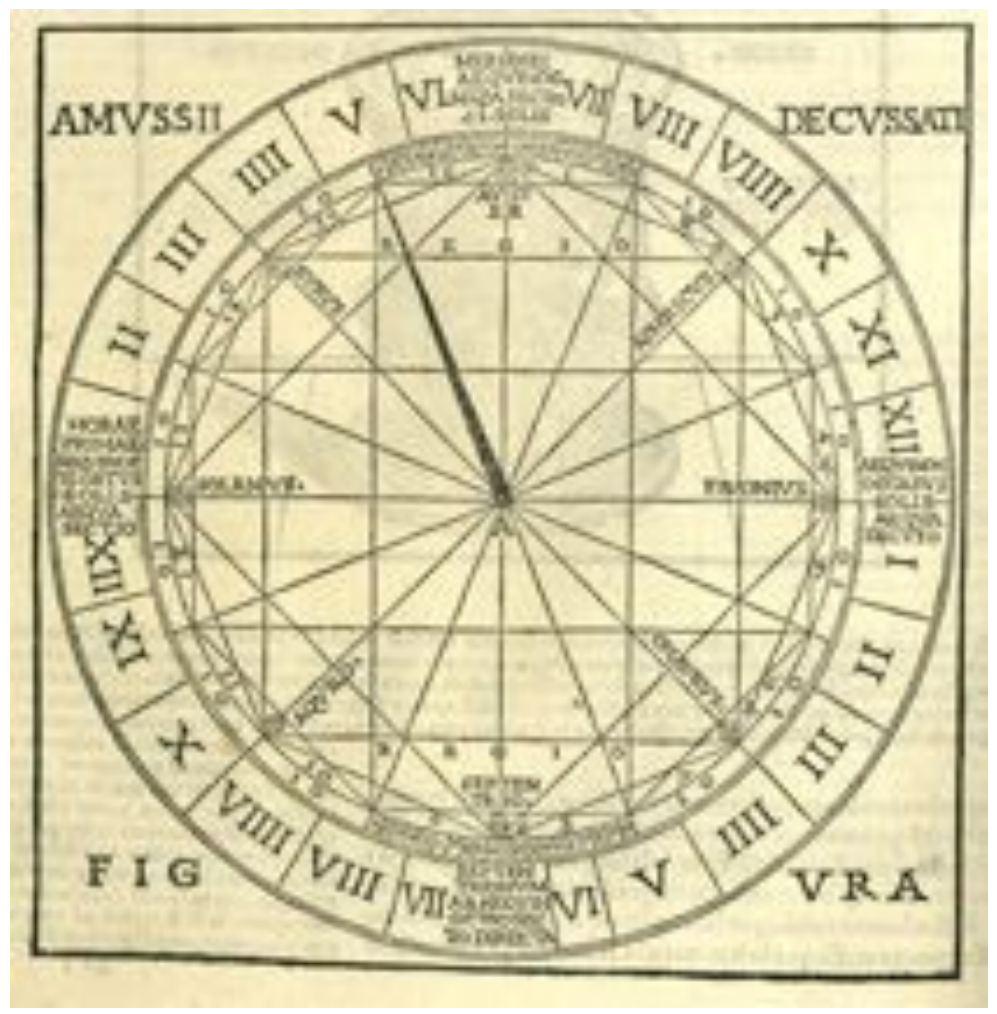

Figure 19 Wind diagram by Cesare Cesariano

Source: Di Lucio Vitruvio Pollione de architecturea libri dece traducti de latino in vulgare afficurati, $25 \mathrm{v}$.

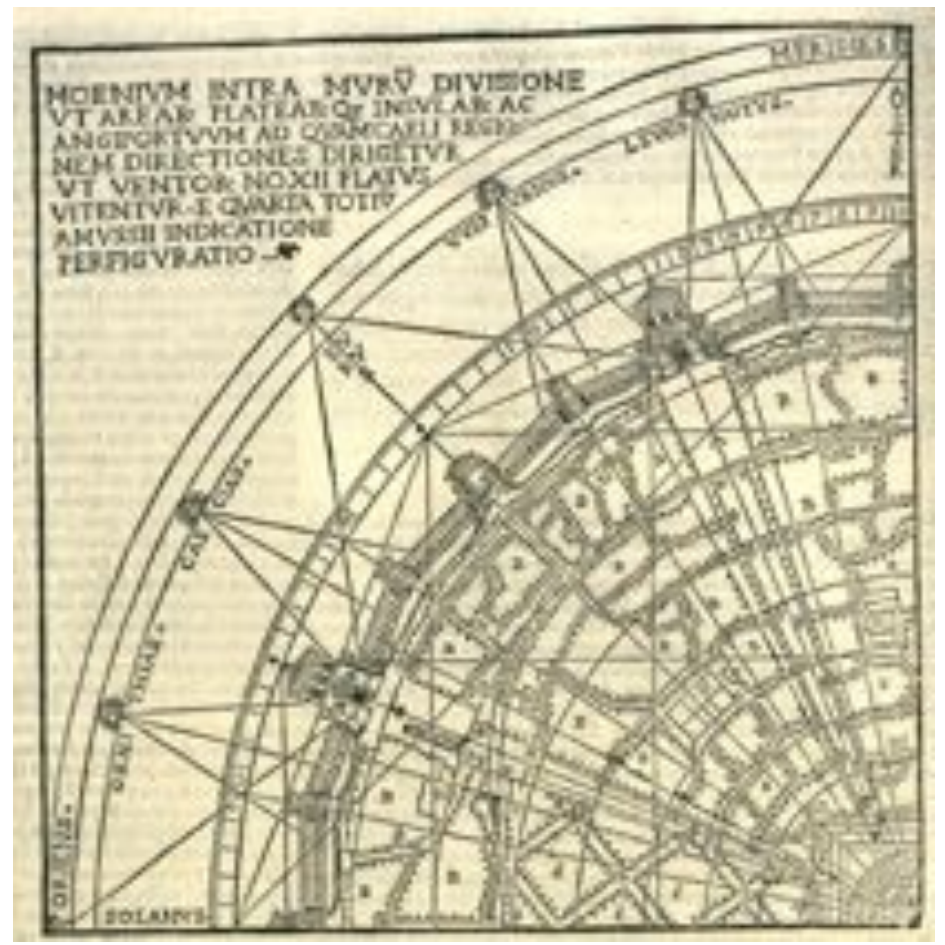

20 City plan by Cesare Cesariano

Source: Di Lucio Vitruvio Pollione de architecturea libri dece traducti de latino in vulgare afficurati, 26v. 


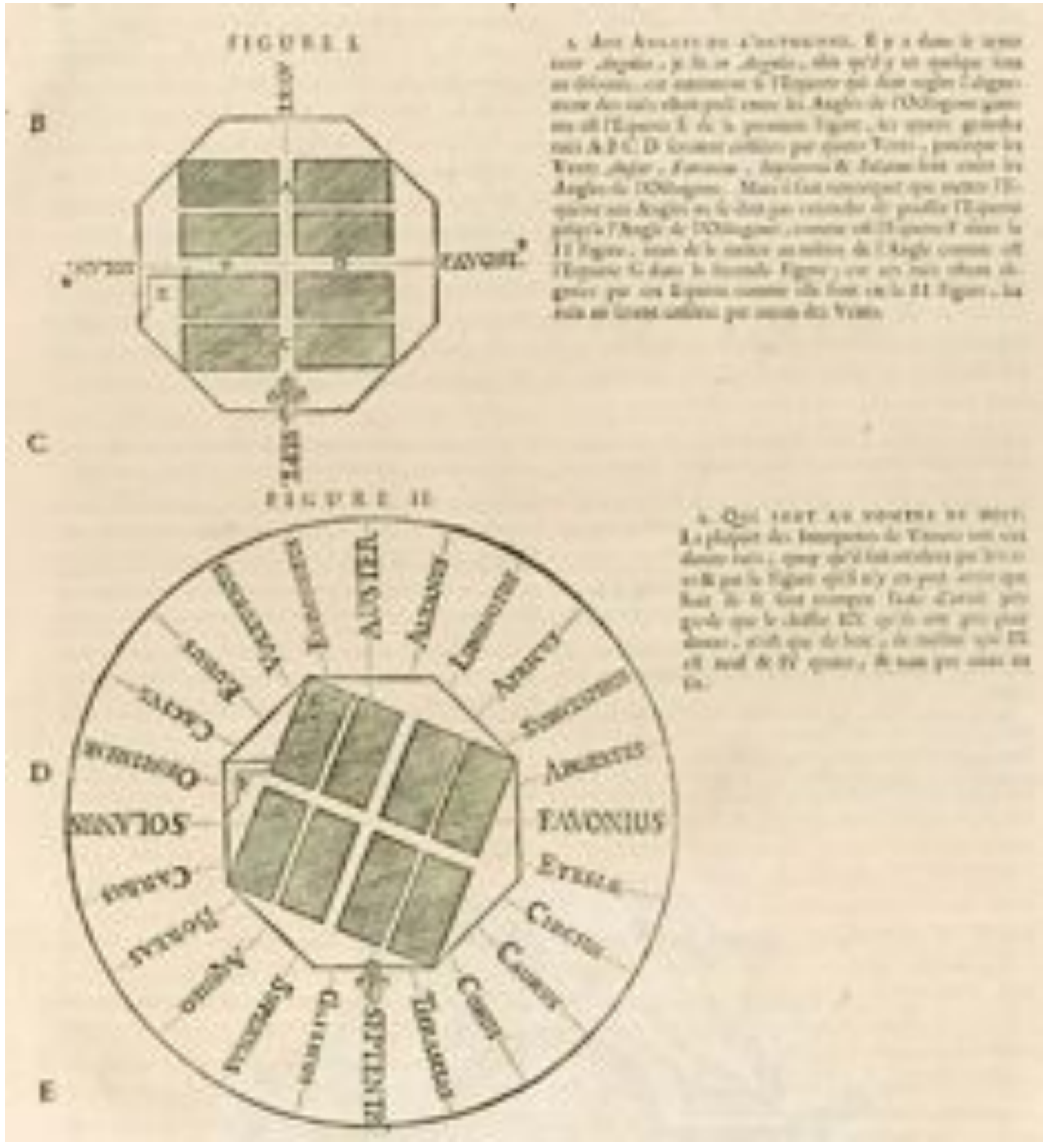

21 Illustrations by Claude Perrault for his translation of Vtiruvius' De architettura

Source: Les dix livres d'architecture de Vitruve, 25. 